\title{
Towards the ex-ante sustainability screening of circular economy initiatives in manufacturing companies: Consolidation of leading sustainability-related performance indicators
}

Kravchenko, Mariia; Pigosso, Daniela CA.; McAloone, Tim C.

Published in:

Journal of Cleaner Production

Link to article, DOI:

10.1016/j.jclepro.2019.118318

Publication date:

2019

Document Version

Peer reviewed version

Link back to DTU Orbit

Citation (APA):

Kravchenko, M., Pigosso, D. CA., \& McAloone, T. C. (2019). Towards the ex-ante sustainability screening of circular economy initiatives in manufacturing companies: Consolidation of leading sustainability-related performance indicators. Journal of Cleaner Production, 241, [118318].

https://doi.org/10.1016/j.jclepro.2019.118318

\section{General rights}

Copyright and moral rights for the publications made accessible in the public portal are retained by the authors and/or other copyright owners and it is a condition of accessing publications that users recognise and abide by the legal requirements associated with these rights.

- Users may download and print one copy of any publication from the public portal for the purpose of private study or research.

- You may not further distribute the material or use it for any profit-making activity or commercial gain

- You may freely distribute the URL identifying the publication in the public portal 


\section{Journal Pre-proof}

Towards the ex-ante sustainability screening of circular economy initiatives in manufacturing companies: Consolidation of leading sustainability-related performance indicators

Mariia Kravchenko, Daniela CA. Pigosso, Tim C. McAloone

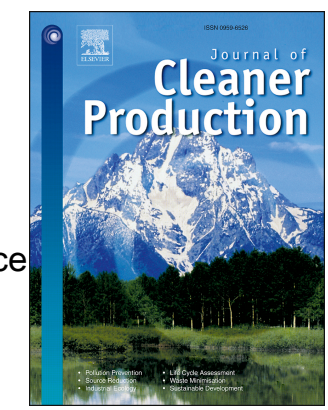

PII: S0959-6526(19)33188-9

DOI: https://doi.org/10.1016/j.jclepro.2019.118318

Reference: JCLP 118318

To appear in: Journal of Cleaner Production

Received Date: 26 April 2019

Revised Date: 2 September 2019

Accepted Date: 5 September 2019

Please cite this article as: Kravchenko M, Pigosso DC, McAloone TC, Towards the ex-ante sustainability screening of circular economy initiatives in manufacturing companies: Consolidation of leading sustainability-related performance indicators, Journal of Cleaner Production (2019), doi: https:// doi.org/10.1016/j.jclepro.2019.118318.

This is a PDF file of an article that has undergone enhancements after acceptance, such as the addition of a cover page and metadata, and formatting for readability, but it is not yet the definitive version of record. This version will undergo additional copyediting, typesetting and review before it is published in its final form, but we are providing this version to give early visibility of the article. Please note that, during the production process, errors may be discovered which could affect the content, and all legal disclaimers that apply to the journal pertain.

(C) 2019 Published by Elsevier Ltd. 
Towards the ex-ante sustainability screening of Circular Economy initiatives in manufacturing companies: consolidation of leading sustainability-related performance indicators

Mariia Kravchenko ${ }^{a}$, Daniela C. A. Pigosso ${ }^{a}$, Tim C. McAloone $^{a}$

a - Technical University of Denmark (DTU), Department of Mechanical Engineering, Nils Koppels Alle 404, Room 226, DK- 2800 Kgs. Lyngby

* Corresponding author. Tel.: +45 2555 65; fax: +45 452519 61. E-mail address: $\underline{\text { makrav@dtu.dk }}$ 


\title{
Towards the ex-ante sustainability screening of Circular Economy initiatives in manufacturing companies: consolidation of leading sustainability-related performance indicators
}

\author{
Mariia Kravchenko, Daniela C. A. Pigosso, Tim C. McAloone
}

Abstract: The concept of Circular Economy proposes an innovative alternative model to counter the failed support of society's current 'linear' mode of operating, with the goal of achieving increased sustainability. A wide range of approaches have been proposed to help businesses plan for and implement circular strategies. Despite positive claims about the potential of circular economy implementation to simultaneously reduce environmental burden whilst enhancing business benefits, not all circular solutions (or circumstances) bring the desired positive effects, especially in the broader context of sustainability. For this reason, any decision to adopt a circular economy strategy ought to be carefully assessed with regards to its potential sustainability performance, prior to its implementation. While several attempts to measure or estimate the sustainability effects of circular economy strategies have been made, they often deploy methodologies that rely on multifaceted input information. Furthermore, such efforts provide results by means of employing lagging indicators, which are complex and may not be easily understood by decision-makers in a manufacturing company context. This paper provides a review of leading sustainability-related performance indicators, identified through a systematic literature review. As a result, more than $\mathbf{2 7 0}$ leading performance indicators have been retrieved and consolidated in a database. Subsequently, these indicators have been classified according to three categories: sustainability dimensions; business processes; and circular economy strategies. The key findings show that leading sustainability-related performance indicators are available for a wide range of Circular Economy strategies, thus making it possible to measure the potential sustainability performance of circular strategies prior their implementation. Furthermore, the specificities of leading indicators available for each classification category are presented, several gaps are identified and direction for future research is established.

Keywords: circular economy, leading indicators, sustainability screening, performance indicators, manufacturing

\section{Introduction}

Circular Economy (CE) is rapidly gathering momentum as the world's leading advocacy associations and governmental bodies recognize the approach as a way of boosting economies, without exploiting the resources at the rate that exceeds the Earth's capacity (European Commission, 2015; WBCSD, 2010). CE is seen as a new business strategy that can be adopted to operate at the global, regional and municipal level (macro level), industrial park level (meso level) and company and product level (micro and nano levels) (Kirchherr et al., 2017). Proposed CE definitions are ample, coming from a wide range of sources, such as scientific literature (see, for example Kirchherr et al. (2017) for the analysis of 114 definitions) to the grey literature, including publications and governmental reports (EMF, 2013; European Commission, 2015). CE as a concept is "...loosely based on a fragmented collection of ideas" (Korhonen, Honkasalo and Seppälä, 2018; p.39), which rest on practices like cleaner production, reliance on renewable energy and materials, elimination of toxic chemicals and waste, increased producers' and consumers' responsibility, and more (Ellen MacArthur Foundation, 2015; Ghisellini et al., 2016). Despite the heterogeneity of definitions and interpretations, CE is seen as a model to support decoupling of environmental pressure from economic growth (European Commission, 2015; Zhang et al., 2016).

In a manufacturing context, circular solutions require redesign of business models, products and supportive networks (e.g. supply chains) to allow businesses to be part of the circular economy system (Geissdoerfer et al., 2018). Examples of CE implementation by manufacturing companies are available and includes strategies such as the provision of product-service systems to intensify the product use and support its operation; circular sourcing and manufacturing with 
focus on usage of secondary raw materials and internal waste recycling; repair and remanufacturing activities to extend the life of products and components. All these strategies seem to be geared by a combination of environmental and business drivers to reduce resource consumption, minimize waste, and boost profitability.

Unsurprisingly, CE is often linked to sustainability, where the adoption of CE practices is expected to facilitate sustainable development, as both concepts rely on promoting economic and environmental prosperity. Notwithstanding these similarities, the relationship between the concepts is thus far not explicit in literature and the positive link between the adoption of CE and sustainability may be seen as 'assumptive'. For example, product leasing is not automatically 'greener' (Agrawal et al., 2012), but might in contrast inspire more frequent product replacement, which will in turn lead to an increase of production. At the same time, result-oriented business models may be more environmentally beneficial than leasing or than conventional product sale schemes (Agrawal et al., 2012; Tukker and Tischner, 2006). Our synthesis of similar literature shows that the relationship between the CE implementation and achieved environmental and financial benefits is ambivalent (see more in Bartolomeo et al. (2003); Moreau et al. (2017); Rizos et al. (2016); and Zink and Geyer (2017)), leading to the conclusion that not all CE initiatives (and not in all contexts) are intrinsically contributing positively to sustainability. Furthermore, several studies indicate social wellbeing as the least prominent objective of CE (Murray et al., 2017; Sauvé et al., 2016), thus contrasting the essence of sustainable development, which rests on the balanced three-dimensional paradigm (i.e. balance between social, environmental and economic dimensions).

In combination to the myriad of CE definitions, the existence of diverging approaches to CE and the ambivalence of statements on potential sustainability benefits of CE implementation risk hampering the uptake of CE in industrial context. Furthermore, in order to ensure a multi-dimensional benefit for sustainability, a holistic thinking approach is needed, where the potential benefits and trade-offs arising from CE implementation can be evaluated. Korhonen et al. (2018) state that no CE initiative or action is successful unless it contributes positively to sustainability, while several other authors (Kalmykova et al., 2017; Potting et al., 2017) highlight the lack of assessment tools that can measure sustainability impact of implemented CE strategies or assess the potential impact of CE strategies before their implementation. The initial attempts to measure environmental effect of CE strategies have been undertaken, frequently executed by employing existing methodologies, such as material flow analysis and life cycle assessment (Elia et al., 2017; Niero and Hauschild, 2017). While these methodologies are extremely useful, their applicability in the context of ex-ante assessment and support for early decision-making is often limited, as they require multifaceted input information and expertise (Arena et al., 2013). Furthermore, the results of these assessments, presented with help of lagging indicators, e.g. eutrophication potential as an impact dimension in a life cycle assessment, are complex and may not be easily understood in strategic and tactical decisions. More discussions stipulate the need for ex-ante assessment approaches to explore whether proposed CE strategies have potential to bring the desired social, economic and environmental effects, in order to support early CE development decisions (Elia et al., 2017). For a meaningful ex-ante sustainability assessment, leading indicators are preferred over lagging, as they can be used to plan and monitor the effectiveness of proposed actions by focusing on critical areas or resolving any uncertainty early in the planning and development process (Pavlov and Bourne, 2011). A deeper discussion about leading and lagging indicators is provided in Section 2.2.

In the light of the status regarding CE and its doubtful link to sustainability, and the importance of evaluating sustainability potential in early stages of CE development, this research aims to cover the identified gap by developing a consolidated database of leading performance indicators to be used for ex-ante sustainability screening of CE strategies in manufacturing context. The main assumption in this research is that leading performance indicators can be used to analyse the potential economic, social and environmental performance of circular solutions in the early stages of the decision-making process. 
The study involves the development of a database in which leading sustainability-related performance indicators are identified and classified according to a number of criteria to support the selection of the most relevant indicators to be employed to support a given decision. This classification allows the configuration of different combinations of circular solutions to be exploited in various business processes, thus displaying a suitable set of sustainability performance indicators to be measured early in the decision-making stage. Performance indicators provide a better insight into strengths and weaknesses of the circular solution, thus enable more informed and balanced decision-making for sustainability. The database of performance indicators is a first building block of a foundation for the development of a sustainability screening framework, which will also comprise a procedure for a systematic indicator selection and guidelines for decision-making for sustainability in a CE context.

The structure of the present paper is in the following order. A relevant review of literature on sustainability assessment and performance indicator is presented in Section 2. Research methodology is elucidated in Section 3, encompassing the methodology and theoretical frameworks adopted in the present study. Thereafter, results of the systematic literature review are presented in Section 4. A discussion of the research findings and identified gaps are provided in Section 5. Finally, conclusions are drawn, based on the goal of the research and the achievements presented in the paper, with suggestions for further work.

\section{Literature background}

This section introduces sustainability assessment and measurement approaches and the role of leading performance indicators in sustainability measurements.

\subsection{Sustainability assessment and measurement}

Numerous definitions of corporate sustainability can be found in the literature (Searcy, 2012), most of which are closely related to the definition of sustainable development, coined by the Brundtland Commission and released in the report "Our Common Future" in 1987 (WCED, 1987). Dyllick and Hockerts, for example, defines corporate sustainability as: "meeting the needs of the firm's direct and indirect stakeholders (such as shareholders, employees, clients, pressure groups, communities, etc.), without compromising its ability to meet future stakeholder needs as well" (Dyllick and Hockerts, 2002). The central focus is the recognition and fulfilment of stakeholder requirements and long-term thinking, which is recognized in other scientific definitions as well.

Despite the widely accepted definition of sustainable development, manufacturing companies are still facing a number of challenges to transform and operationalize the concept at a practical level (Joung et al., 2013; Pavlovskaia, 2014). The main interpretation of the concept of 'sustainable development' has been primarily aligned with the 'Triple Bottom Line' (TBL) approach, based on the management of and contribution to environmental integrity, social well-being, and economic resilience (Elkington, 1998). Therefore, companies develop and implement practices that focus on gaining and maintaining economic advantages while minimizing environmental burden and maximizing social prosperity. Sustainability performance measures can be applied to trace how 'much' and how 'well' implemented practices helped the company to move towards sustainability by advancing in the TBL domains. Internationally recognized standards and guidelines like ISO 14031; the Global Reporting Initiative (GRI); and the UN Global Compact, have been voluntary used by corporations to measure and track performance in sustainability dimensions.

When it comes to measuring sustainability performance of improvement initiatives, sustainability assessment is often used to evaluate how well the chosen sustainability requirements were fulfilled. Sustainability requirements can be understood as criteria that must be fulfilled for a specific element or activity (i.e. manufacturing process, product or service), in order to be considered sustainable (at least in relation to the element or activity that have not fulfilled the same requirements) (Krajnc and Glavic, 2003; Pavlovskaia, 2014). For that reason, the identification, integration and fulfilment of sustainability requirements for products and operational activities can be considered as interpretation and 
operationalization of the theoretical concept of sustainability by practitioners. Depending on the implementation level, different sustainability criteria exist. For manufacturing processes, for example, such criteria are (but not excluded to) efficient use of energy and materials for reduced operational costs, minimization of pollution and safe work environment (Amrina and Yusof, 2011; Joung et al., 2013; Krajnc and Glavic, 2003).

Sustainability assessment, therefore, is a procedure that aims at evaluating whether the improvement initiative has the potential to contribute to sustainability in a short and long-term perspective (Ness et al., 2007; Pope et al., 2004). Referring to the works of Pope et al. (2004) and Waas et al. (2014), the purpose of any sustainability assessment is to:

- Contribute to a better understanding of the meaning of sustainability and its contextual interpretation;

- Integrate sustainability into decision-making by identifying and assessing (past and/or future) impacts;

- Foster sustainability objectives.

Literature distinguishes between different forms of sustainability assessment: ex-ante assessment, i.e. the assessment of future actions, durante (during), and post evaluation, the assessment of past actions and their outcomes (Pope et al., 2017); and different types of assessment, based on a number of approaches, for example, monetary, biophysical, indicator-based (Gasparatos and Scolobig, 2012). Of the three sustainability assessment approaches, the indicator-based approach seems to offer the best possibility to plan, monitor, control and quantify sustainability contribution of certain improvement initiatives in a short and long-term perspective (Rotmans, 2006). Other advantages of using indicators for sustainability assessment include their role for comparison of alternatives and highlighting potentials for optimization (Azapagic and Perdan, 2000); helping to structure, summarize and condense complex information for meaningful interpretation (Waas et al., 2014); inducing learnings about significant sustainability aspects and impacts within or outside the company (Krajnc and Glavic, 2003). In summary, indicators enable detection, monitoring, quantification, assessment and interpretation of the performance of organizations, operational processes and products in terms of their potential (expected) or achieved (actual) sustainability impact.

\subsection{Performance indicators for decision-making}

Waas et al. (2014) define an indicator as "the operational representation of an attribute (quality, characteristic, property) of a given system, by a quantitative or qualitative variable (parameter, measure)...". Sustainability indicators can be categorized according to the TBL categories, measuring the performance or impact of the improvement actions within environmental, social and economic domains. Examples of indicators are 'number of accident-free days', 'number of suppliers with certified according to ISO14001', 'employee satisfaction', 'percent of primary raw materials replaced by secondary raw material in a product', 'total water consumption', 'climate change', 'resource depletion' and more (additional indicators available from LCA, S-LCA, GRI, etc.). Furthermore, sustainability-related indicators can be categorized into so-called 'leading' and 'lagging' indicators.

Lagging indicators are often referred to as reactive indicators, as they help measuring the effect of actions that are already approved and undertaken by the company. They are used for past performance assessment to measure the final outcomes of the implemented initiatives. Lagging indicators are widely employed by different methodologies, e.g. LCA (climate change indicator) and in corporate reporting, e.g. $\mathrm{GRI}\left(\mathrm{CO}_{2}\right.$ indicator) as they serve as a good proxy for corrective actions (Epstein and Roy, 2001).

In contrast to lagging indicators, leading indicators are referred to as proactive indicators, because they can be used to plan and monitor the effectiveness of proposed actions and give advance guidance and warning, hence the possibility for companies to adjust and improve the solution (Pojasek, 2009). Leading indicators serve as preventive 'signs', i.e. they assist decision-makers with information to introduce improvements in the early stages of decision-making process, thus allowing greater control over 'allocation' of future impacts (Fig. 1). Distinctively, the uncertainty of data in the early stages may be greater, while the measurability decreases with time along the causal chain from input to impact (von Geibler et al., 2016). 


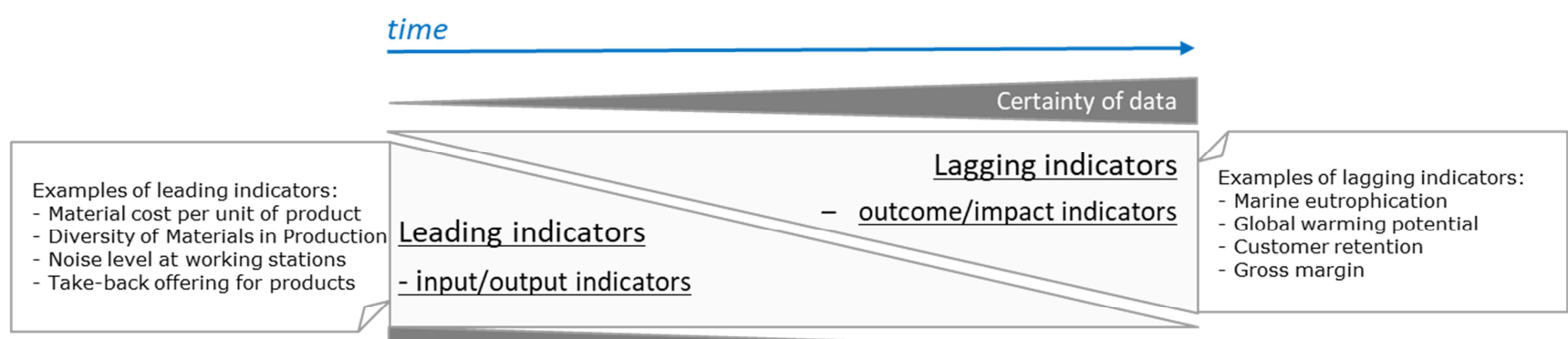

Measurability and control over impact

Fig. 1. Distinction between leading and lagging indicators and their relationship to time. Source: own figure, based on Pojasek (2009) and von Geibler et al. (2016: 1).

Following McAloone and Pigosso (2018) on the use of indicators for product development, leading environmental performance indicators aim to produce simpler measures (compared to, for example, LCA results) of environmental aspects that can inspire effective actions towards improving products' environmental performance. Examples of leading indicators include 'take back cost of used products', 'product hazardous materials', 'total number of fasteners in a product', and more. Leading indicators are, therefore, generally thought of as input or process indicators that link more closely to operations and products, while lagging indicators relate more to outcomes achieved (Fig. 1).

Leading indicators go beyond data and measurements as they become 'subjective', i.e. have to relate to some situation, serve some person, and serve some purpose. Indicators help to structure information in a meaningful way, which leads to knowledge creation about a certain context, thus can support decision-makers in the identification and understanding of the relationship between the decisions to be taken and the potential impact on performance (Epstein and Roy, 2001) (Fig. 2).

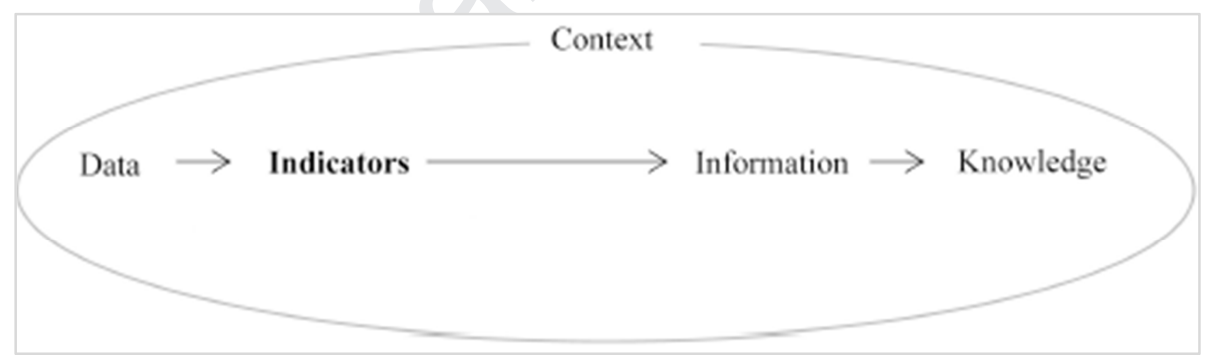

Fig. 2. Transitional role of indicators from data to knowledge formation. Source: modified from Waas et al. (2014).

Researchers Epstein and Roy (2001) and Morioka and Carvalho (2016) advise using leading indicators for performance measurements more extensively, as they provide insight into the organization's, operation's or product's potential impact and provide indications about future performance. Lagging indicators, while being equally important, provide information on past performance of the system, however may not offer useful information about the exact causes of such performance, thus may not be effective for decision-making and management of processes (Pojasek, 2009).

Following the importance of the role of performance indicators in sustainability assessment and the importance of leading performance indicators in effective management of processes, it can be argued that the approach for assessing the sustainability of CE initiatives in the early stages of a decision-making process should be based on leading performance indicators. Therefore, this study focuses on the development of a consolidated database of leading performance indicators to be employed for ex-ante sustainability screening of CE initiatives. The database comprises leading performance indicators that were classified according to TBL dimensions, CE strategies applicable on a microlevel and business processes. Therefore, the core of the development of the database was the process of identification 
of leading sustainability-related performance indicators and their classification according to the identified criteria. The process is described in detail in Section 3 - Research methodology.

\section{Research methodology}

This study focuses on the development of a consolidated database of leading performance indicators to be employed for ex-ante sustainability screening of CE initiatives. The goal of this research was to identify leading sustainability-related performance indicators in the literature and classify them according to business processes and CE strategies, with the ultimate aim to support decisions for CE planning and implementation. Therefore, the question in focus was: "What are the existing sustainability-related leading indicators that can be used to measure the sustainability performance of $\mathrm{CE}$ initiatives?"

\subsection{Data collection}

A systematic literature review was performed to answer the question in focus. The research approach consisted of, firstly, extracting the existing indicators from the literature and, secondly, classifying performance indicators according to the defined criteria. Systematic reviews are conducted with the aim of identifying all research within a specific scientific area to give a "balanced and unbiased summary of the literature" (Nightingale, 2009). Systematic literature reviews follow a specific procedure that is rigorously planned, conducted and documented (Biolchini et al., 2005), thus minimizing the risk of bias in selecting and extracting data from the review (Nightingale, 2009).

The systematic literature review followed the procedure proposed by Biolchini et al. (2005) consisting of: (1) review planning; (2) review execution; and (3) results analysis (Fig. 4). In the first step of the procedure, review planning, a systematic literature review protocol was prepared to document the aims and objectives of the review, inclusion and exclusion criteria, the way in which studies were identified and how the results were registered. During the second step, review execution, the identified studies were evaluated and screened against the inclusion criteria defined in the protocol. Lastly, the selected studies allowed retrieving relevant data to be analysed and registered according to the procedure (Biolchini et al., 2005).

The main goal of the systematic literature was to identify and consolidate information on leading performance indicators that form a foundation for the database to be used for decision-making. The review focused on identification, selection and systematization of leading sustainability-related performance indicators. A literature search was performed in the databases Scopus and ISI Web of Knowledge, due to availability of advanced web search mechanisms, high volume of indexed papers and proven relevance in the fields of sustainability and engineering (Adriaanse and Rensleigh, 2013; Falagas et al., 2007; Gavel and Iselid, 2008). Search strings were composed of the main keywords and their synonyms, as identified and supported by literature.

According to works of Ahi and Searcy (2015), Costa et al. (2014) and Veleva and Ellenbecker (2001), terms as 'performance measure', 'performance evaluation', 'performance assessment' and 'performance indicator' are used interchangeably, therefore were all included as synonyms to the key word 'key performance indicator', thus comprising the first part of the search string. In relation to sustainability assessment, the literature is in consent of sustainability should be viewed and measured from a holistic perspective, e.g. encompassing social, environmental and economic dimensions (Bell and Morse, 2008). Therefore, it allows to interpret sustainability as a 'three-pillar' or 'triple bottom line' (TBL) concept (Pope et al., 2004). Consequently, the second part of the search string consisted of words 'sustainability', 'triple bottom line', 'social', 'environmental' and 'economic'. The third part of the search string consisted of a number of certain business processes that the current research encompasses. The business processes are seen as the 'arenas' within which CE initiatives are developed and materialised, i.e. circular solutions are to be planned for and evaluated during and across business processes. The business processes considered in this research were 'business model development'; 'product development'; 'production and operations'; 'after-sales service'; and 'end of life operations'. In 
Scopus, the keywords were searched for in the titles, abstract and keywords. After a set of refinement rounds, it was decided to limit the research fields ('subject area' in Scopus) to cover environmental science, engineering, business, economics, social sciences and decision sciences. The search included both journal and peer-reviewed conference papers, in order to capture the recent developments in the field. Furthermore, no restrictions were applied to the publication year, in order to guarantee comprehensiveness of the results. As Nightingale (2009) points out, the search strategy should be 'sensitive' rather than 'specific' to increase the chance of getting 'important' papers despite the possibility of getting a large number of irrelevant papers. The search string used in Web of Science was composed and adapted to the database's rules. After a set of refinement rounds, it was decided to search for the key words only in the titles of the studies (refer to Appendix A for exact search strings used in Scopus and Web of Science).

The inclusion criteria, defined in the review planning protocol, were used to identify, evaluate and select the relevant studies. The inclusion criteria ensured the homogeneity of the data and reduced confounding. The studies met the following inclusion criteria: 1) proposition, application or review of a leading indicator for sustainability assessment; 2 ) focus on manufacturing companies or micro-level (product, process, service). With the first inclusion criteria, the review intended to exclude lagging indicators used for sustainability assessment, such as global warming potential or abiotic toxicity (often used in LCA studies), whereas with the second inclusion criteria, any indicator that focuses on municipal or national level were excluded. Considering the inclusion criteria, the publications were qualitatively selected according to the gradual application of three filters: filter 1 - read the title, abstract, key words; filter 2 - read introduction and conclusion; filter 3 - read the full paper.

After all the studies were screened and the indicators identified, they were registered with the following attributes: name of the performance indicator, a detailed description, formula, unit of measurement, recurrence in literature and source. References, cited in the publications identified through the search, were used as secondary sources to identify additional relevant publications. This procedure is sometimes called a 'snowball technique' or cross-referencing (LewisBeck, 2004). This process led to identification and analysis of a number of studies that contributed to the data extraction.

\subsection{Data systematization}

The second phase of the performance indicators systematization included the classification according to a number of pre-defined categories, such as circular economy strategies, business processes and TBL dimensions (as shown in Fig.3):

Sustainability or triple bottom line dimensions: environmental, social and economic, where all three pillars are considered equally important when making decisions and measuring performance in the sustainability context (Badurdeen et al., 2015; Joung et al., 2013). These are categories widely used by other sustainability assessment and measurement frameworks. Therefore, this classification of performance indicators allows for a holistic assessment of CE initiatives and enables a straightforward association of each indicator with a specific sustainability dimension and an aspect under it.

- Social dimension is defined as the dimension that addresses identification, accounting and management of values and needs of different stakeholders of a company (UN, n.d.). The stakeholders can be identified as internal and external groups of people that interact with and directly or indirectly affected by the company and its activities (Labuschagne et al., 2005). In the context of social business sustainability, the key stakeholder groups required by most global standards and frameworks (such as GRI, UNCSD, S-LCA) are employees, customers, suppliers and community (local, national, or global). Each group requires addressing a number of related aspects, such as but not excluded to: employment conditions, health and safety of employees and customers, human rights, equity, etc. Therefore, the categories under social dimension included in the database are: community relationships; employee 
empowerment; employee health and safety; employee training and education; employment conditions; equality; supplier relationships; user relationships.

- Economic dimension represents positive value creation and distribution by a company supported by long-term relationships with customers, partners and suppliers (Elkington, 1998). The aspects covered under economic dimension and frequently used in corporate reporting are: costs, revenues, investments, innovation and technologies, knowledge management, etc. The aspects included in the database address tactical and operational matters and are: operational costs; tactical costs; user costs; product quality; revenues.

- Environmental dimension concerns the identification and management of organization's aspects and impacts to ensure long term positive impact on living and non-living natural systems (Bell and Morse, 2008; Sauvé et al., 2016). Aspects that belong under environmental dimension capture resource consumption (material, energy, water, land), emissions to water, soil, air, and chemicals (Fiksel et al., 1998; Joung et al., 2013) and are most common aspects in performance measurements and reporting frameworks (e.g. by GRI Sustainability Reporting Standards; OECD sustainable manufacturing indicators; ISO 14031: Environmental performance evaluation standard). Aspects under environmental dimension included in the database are: material, energy and water consumption; solid and liquid waste generation; air, water and soil pollution; gaseous emissions; land use; material safety; product architecture (i.e. physical properties and attributes of a product, which, for instance, can influence the cost of maintenance or repairability).

Each performance indicator was classified according to a corresponding dimension, mainly justified by a unit of measurement the indicator had assigned to it. We, however, acknowledge that most of the retrieved sustainabilityrelated indicators are cross-dimensional (Badurdeen et al., 2015). For instance, hazardousness of materials in a product can have an impact on both, environment and consumer; however, the indicator measuring the weight or number of hazardous materials in a product was assigned to 'material safety' aspect under environmental dimension. Resource origin is another example of cross-dimensional aspect between environmental and social dimensions. The indicator 'amount of conflict resources' measuring the amount of resources used in a product or production that are extracted in a conflict zone that may perpetuate violence (European Commission, 2017) was assigned to both, the environmental and social dimension, while the indicator 'suppliers that have completed information on raw material and resource origin' was assigned to the social dimension.

CE strategies applicable in a manufacturing context served as another category for indicator classification. There are numerous frameworks that propose a vision for how to operate in a CE context. Those frameworks propose strategies based on their generic applicability, such as the ReSOLVE framework (EMF, 2013), applicable to specific sectors (i.e. textile) ("The new textile economy" by EMF, 2017), or to specific operational processes and products (supply chain, design of products and business models for circularity, etc.) (Bocken et al., 2016). In this research, a generic reference model (i.e. applicable to any sector, process or product type within manufacturing context) was adopted with the following CE strategies as depicted in Fig. 3 and listed in Appendix B with corresponding definitions. The framework of CE strategies adopted in this study is an instantiation of Potting et al. (2017), which was selected because it provided an overview of the spectrum of available circular strategies ranging from incremental to transformative. Each performance indicator was classified according to a corresponding CE strategy. The classification was done based on the correlation between the activity implied by a CE strategy and the focus of indicator measurement. For instance, the indicator 'cost of remanufacturing" was assigned to the CE strategy 'Remanufacture'; the indicator 'water consumption during use phase of the product' was assigned to the CE strategy 'Reduce, Restore \& Avoid impacts in Product in Use stage'; while the indicator 'weight per distance travelled' was assigned to every CE strategy as transport is an aspect applicable across strategies. The classification of performance indicators according to various CE strategies allows the decision maker to extract the indicators meaningful to the circular solution in focus. 


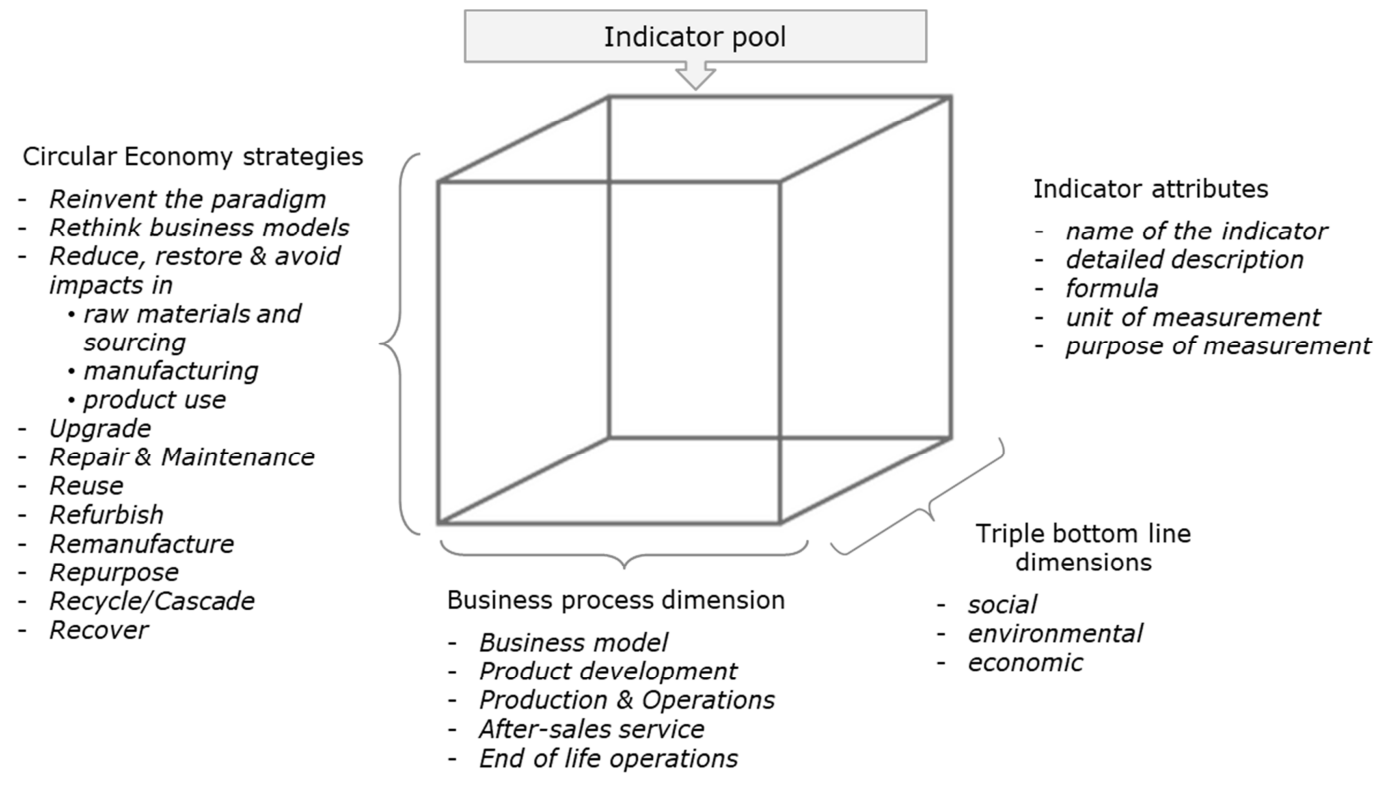

Fig. 3. Data systematization process: classification of performance indicators according to the circular economy strategies, business processes and TBL dimensions.

Business processes are a set of structured activities that a company manages in order to accomplish a specific purpose, for instance, to produce a product or service (Ray et al., 2004). Business processes can be classified as primary, related to operational activities (e.g. product development, inbound and outbound logistics, manufacturing, service provision) and secondary, related to management activities (e.g. corporate governance and strategic management) (Persson and Stirna, 2009). The business processes considered for indicators classification in this study are related to primary organisational activities, such as product development (PD), production and operations process (including supply, distribution and retail), after-sales service (including installation of product, support of product, upgrade and repair services), end of life operations (EoL) (including remanufacturing and recycling) and business model (BM) development. These processes belong to the primary business processes and are typical for any manufacturing company (Ray et al., 2004). The rationality behind the classification of performance indicators according to these business processes was the extent to which an indicator can be influenced by a decision taken during a particular business process. For example, the number of modules in a product is decided upon during a product development process; therefore, the indicator 'number of module sin a product' was assigned under 'product development' process.

\section{Results}

The results are presented and discussed in several sub-sections. Sub-section 4.1. provides the detailed analysis of the literature collected and reviewed during the systematic literature review; sub-sections 4.2., 4.3. and 4.4. address the results of indicator classification according to the defined categories: 4.2. - for TBL classification, 4.3. - for business process classification, 4.4. - for CE strategy classification.

\subsection{Background information on the literature}

Using the procedures discussed above, a total of 665 articles (521 for Scopus and 144 for Web of Science) were originally identified through the search in both databases. At the end of the screening process guided by the inclusion criteria, the final number of papers that were used to retrieve performance indicators was 17; however, 35 relevant papers were also included as a result of paper analysis from cross-referencing (Fig. 4). By applying the inclusion criteria, all the papers had their title, abstract and key words analysed, resulting in 506 papers (76 \% of total) being rejected. The chosen 159 papers (24\%) had their introduction and conclusion read, resulting in 60 papers chosen. Finally, the 60 papers were fully read, from which 17 were chosen for the retrieval of performance indicators. In continuation of this study, around 70 
papers found through cross-referencing were analysed against the inclusion criteria, with 35 being consequently chosen for performance indicator extraction. Thus, the total number of papers that satisfied the inclusion criteria amounted to 52.

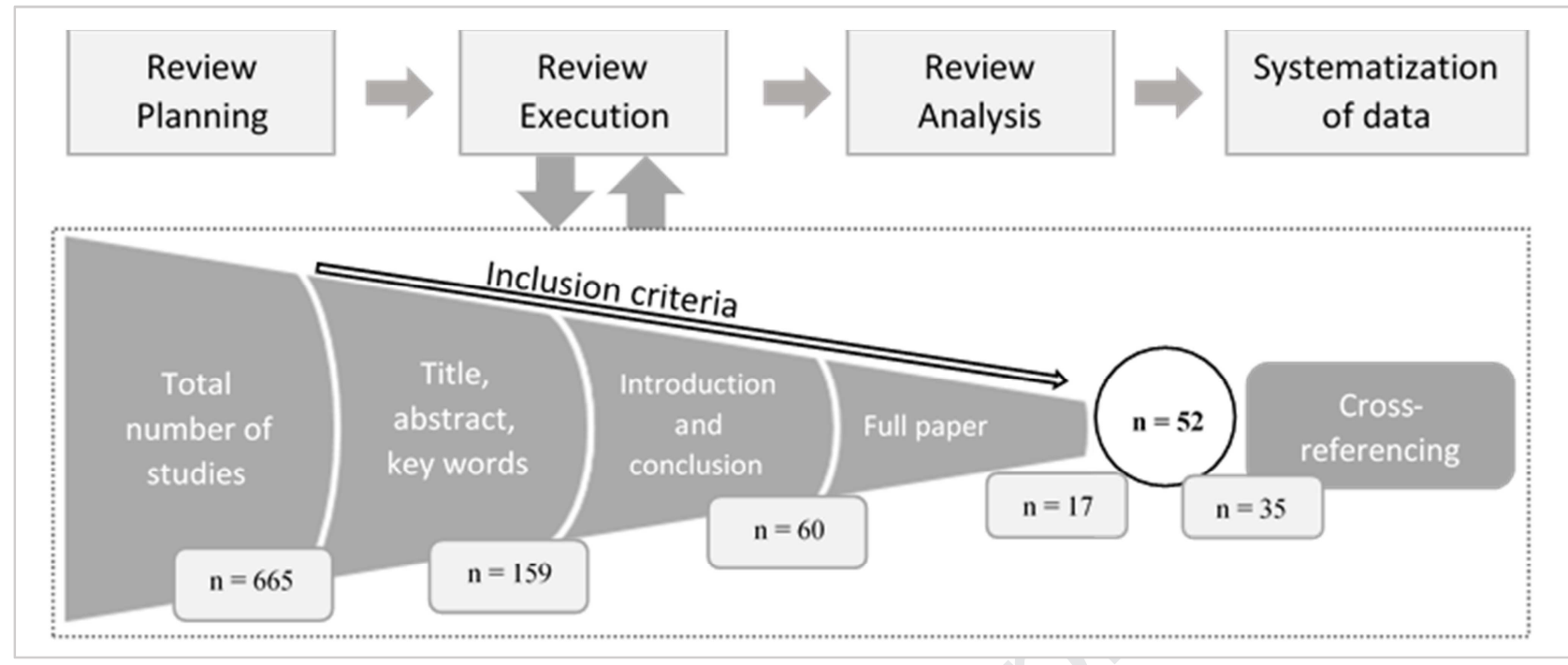

Fig. 4. The research approach: the systematic literature review process and selection of relevant studies.

The selected papers were published in a total of 25 different journals, 3 handbooks and 8 scientific conference proceedings in the period $1994-2018$ with larger dominance of publications from 2012 - 2018 (Fig.5). As seen in Fig. 5, showing the distribution of papers by conference (grey bars), one paper was identified in every conference with the only exception of the proceedings of International Conference on Industrial Engineering and Engineering Management (IEEM) and IFAC conference proceedings, from which three and two publications were extracted correspondingly. The largest number of papers (11 publications) were extracted from the Journal of Cleaner Production, which can be explained by the Journal's strong correlation with cleaner production, environmental issues, and sustainability concerns (Fig. 5, blue bars). Furthermore, the International Journal of Production Research, Ecological Indicators and International Journal of Life Cycle Assessment presented two publications each, which might be attributed to the primary focus of abovementioned journals and its relation to the present question in focus (performance indicators for sustainability assessment in a manufacturing context). The remaining publications came from a variety of journals addressing different themes, such as mechanical and sustainable design, resources, production economics, and clean technologies.

From the 52 publications, approximately 400 leading sustainability-related performance indicators were retrieved and reviewed. The duplicates were removed and the indicators were registered in the database developed in a spreadsheet with a total number of 279 indicators. The consolidation process included registration of each performance indicator in a database with the corresponding attributes, such as name of the indicator, a detailed description, formula and unit of measurement. Approximately $90 \%$ of the performance indicators were accompanied by explicit units of measurement, however the description and formulas were not always provided. These missing attributes were defined and registered in the database complemented by a description of 'purpose of measuring', to aid the understanding of importance of the indicator and interpretation of measure. Important to note that almost $95 \%$ of extracted indicators are quantitative despite the fact that qualitative indicators were not targeted to be excluded during the literature review.

After the review process, the indicators were classified according to the pre-defined dimensions, i.e. TBL dimensions, business processes and CE strategies. Since this research is exploratory in nature, we highlight the distribution of performance indicators according to the pre-defined criteria to show recent developments in an indicator categorization and their deployment in sustainability assessments. 


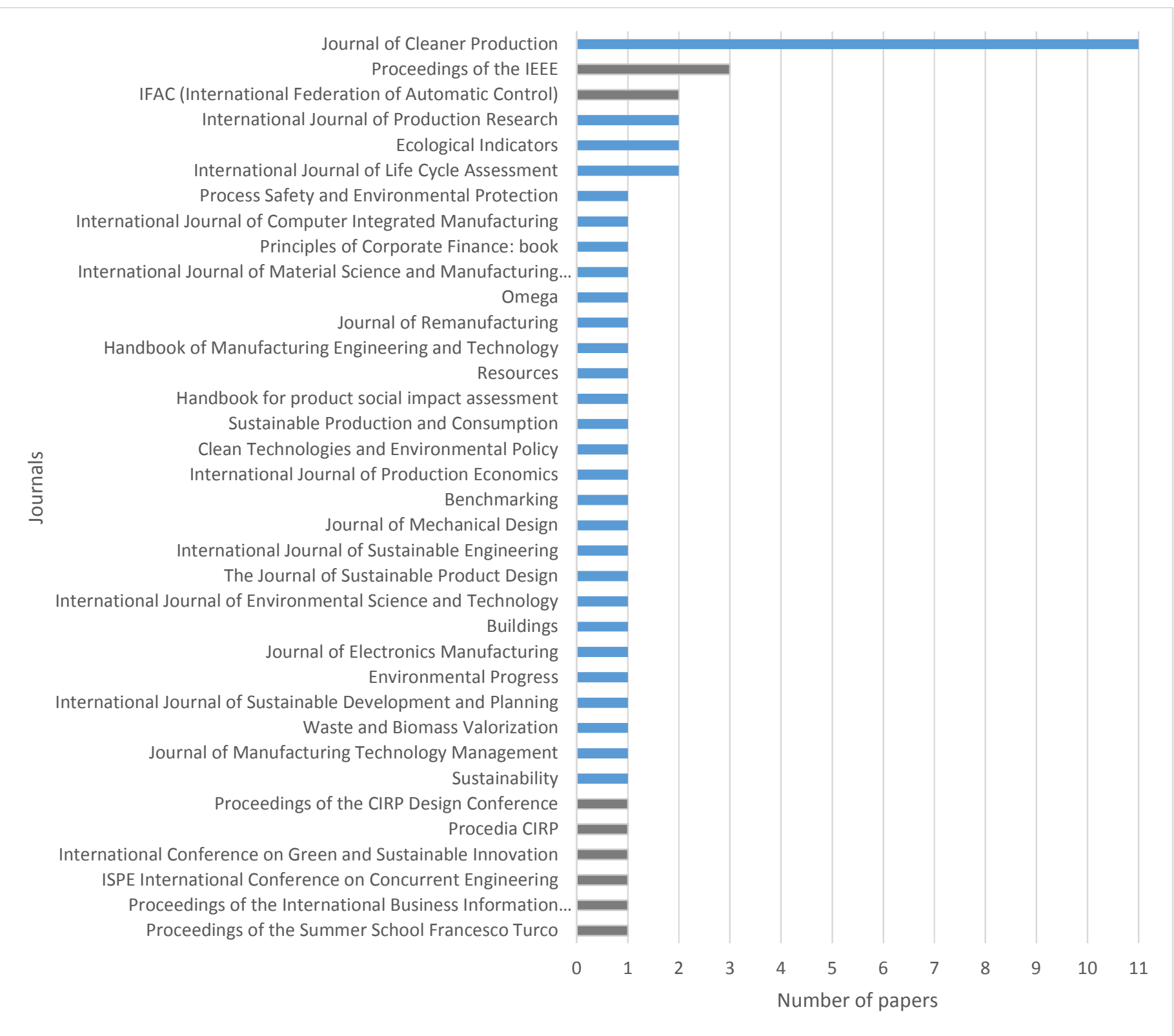

Fig. 5. Distribution of selected publications by journal (in blue) and by conference (in grey).

\subsection{Analysis of performance indicator classification according to TBL dimensions}

Each performance indicator was classified according to the TBL dimension: social, environmental and economic, respectively. Furthermore, each performance indicator was assigned to an aspect within a particular dimension (Fig. 6), thus illustrating what sustainability dimension and what aspect of that dimension the indicator measures the performance of. As an example of how categorization was done, the performance indicator 'total packaging costs' was classified as an indicator primarily related to the 'Operational cost' aspect under economic dimension, mainly justified by the assigned to it monetary unit of measurement. However, it also relates to the 'Material consumption' aspect under environmental dimension. For the purpose of a clearer identification of the sustainability dimension a particular indicator belongs to, the classification was done according to the descriptions of sustainability dimensions provided by the literature and corresponding units of measurement (see Section 2). To further explain the classification logic, the indicators that addressed consumption of materials, energy, chemicals, water, land, emissions and pollution were all classified as environmental indicators; the indicators that addressed costs and revenues were classified as economic 
indicators; the indicators that addressed stakeholder relationships, employment conditions, customer and community relationships were classified as social indicators.

The total number of performance indicators distributed per TBL dimension and per corresponding aspect are shown in Fig. 6. The environmental dimension has the largest number of aspects as well as the largest number of indicators assigned under those aspects. Performance indicators from environmental dimension represent $61 \%$ (170 out of 279) of all the indicators extracted from literature with the highest number of performance indicators measuring performance on material consumption, energy consumption, product architecture and solid waste generation. The 'product architecture' can be considered as a neutral aspect as it relates to design attributes of a product, nonetheless it has a critical effect on the way a product performs. Performance in 'product architecture' is especially crucial in the context of $\mathrm{CE}$, as it influences whether the product can be repaired or recycled, consequently affecting the efficiency of those processes in terms of waste generation, energy and material consumption, and cost. Furthermore, performance indicators that measure performance on material, energy and water consumption were most frequently mentioned under their dimensions in the literature (Fig. 6). The 'Soil pollution' aspect was addressed by only one indicator, 'pesticide use', while none of the retrieved indicators covered 'land use' aspect.

A total of $23 \%$ (63 out of 279) of the performance indicators were classified under the economic dimension with the aspect 'operational costs' being the richest on indicators. It is also the aspect with the most frequent mention of the performance indicator 'total material costs' (5 publications). Other economic indicators measure performance on such aspects as 'tactical costs' (e.g. 'cost of supplier education and training'), 'revenues' (e.g. 'revenues from refurbished products'), 'user costs' (e.g. 'cost of energy during use phase of the product'), 'product quality' (e.g. 'first technical wearout life'). 'Product quality' aspect is considered under economic dimension due to its materiality in influencing customer satisfaction, and profitability, consequently (Gaiardelli et al., 2006).

The social dimension accounts for the least number of performance indicators corresponding to $16 \%$ (46 out of 279) of all indicators retrieved from the literature. Most indicators under social dimension relate to employee-related aspects (working conditions, health and safety, training and education), thus confirming the 'tradition' from manufacturing sector of concentrating social performance measurements on 'inside-out' social aspects (Chengcheng Fan et al., 2010; Feil et al., 2015). Remarkably, it is also the aspect with the most frequently mentioned indicators in the literature, with the indicator 'health and safety training per employee' and 'total number of hours of capacity and skill development training per employee' mentioned in 12 publications (Fig. 6). Although the developments in taking social aspects beyond operational activities, such as adoption of CSR policies and Global Compact Principles, has contributed to the development of indicators capturing community, supplier and user relationships (Husgafvel et al., 2014), their number is relatively small. 


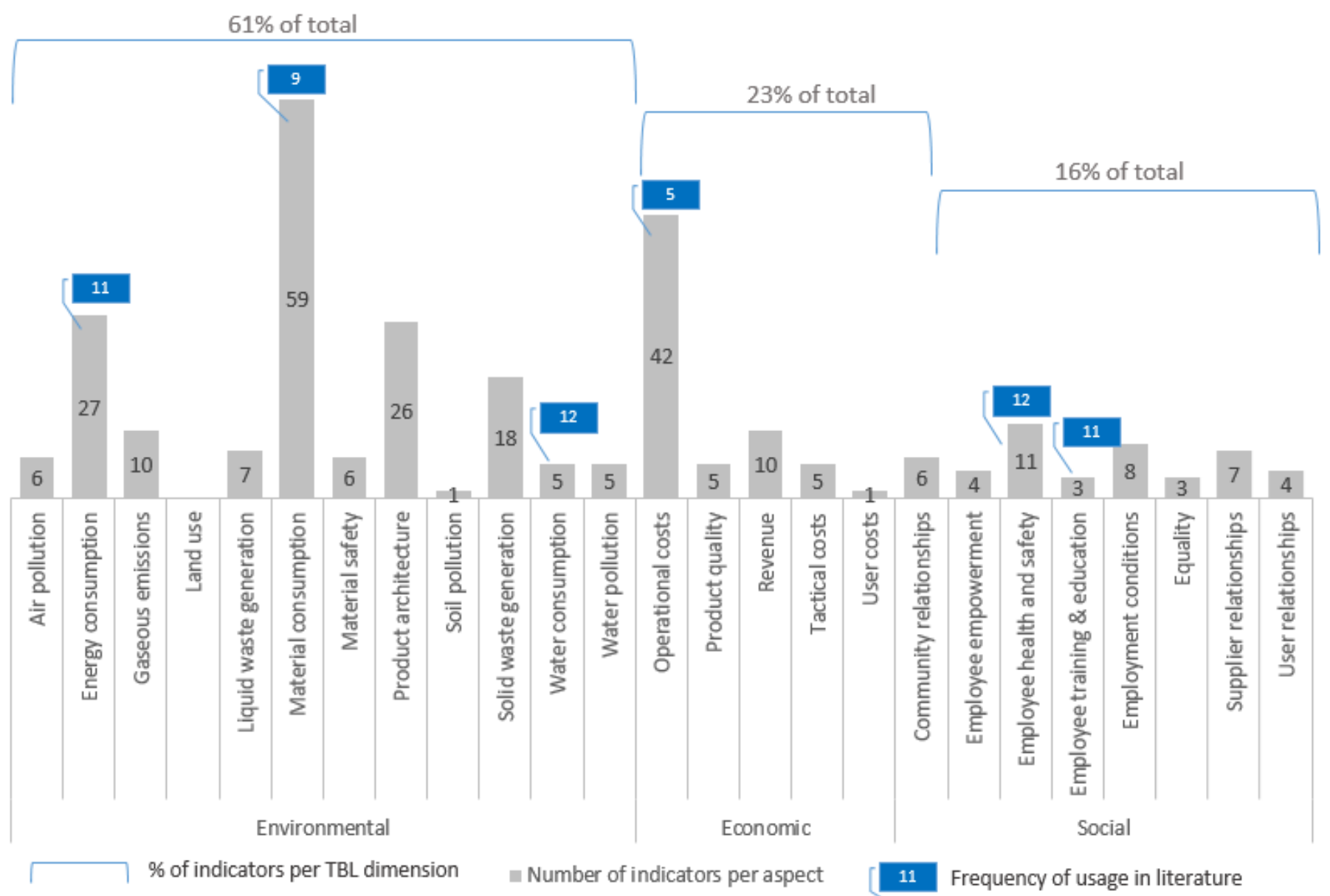

Fig. 6. Total number of performance indicators capturing TBL dimensions and corresponding aspects, where blue bars highlight aspects, covered by indicators most frequently proposed in the literature.

\subsection{Analysis of performance indicator classification according to Business Processes}

Business Processes served as another category for indicators classification. As an example of how classification was done, the indicator 'waste converted to reusable material' was classified under 'End of Life operations' process, since the amount of waste converted to reusable material can be influenced by a decision taken during EoL operations. The distribution of performance indicators across business processes and corresponding TBL dimensions is shown in Fig. 7. The most extensively covered process is 'production and operations', represented by $76 \%$ (211 out of 279) of performance indicators, $65 \%$ of which belong to the environmental dimension. This might be, firstly, due to a larger focus in the literature on sustainable manufacturing performance measurements, secondly, due to the expansion of sustainability-related metrics from manufacturing, to supply chain orientation, with attention turned to a more 'inclusive' and 'external' consideration of sustainability performance during supply, distribution and retail operations (Ahi and Searcy, 2015). This is confirmed by the literature the identified indicators were drawn from. Thus, the environmental indicators include 'total material consumption', 'total energy consumption', 'total waste generation', (Amrina and Yusof, 2011; Kafa et al., 2013; Lu et al., 2010), 'fuel consumption in transportation for raw materials' (Olugu et al., 2011), most originating from literature on sustainable and green supply chain measurements. Similar rationality applies to social indicators, which tend to account for 'internal' stakeholders aspects, such as employee health and safety, employment conditions and training and education (Kafa et al., 2013). Despite the supply chain view, which suggests a broader scope of social aspects, social dimension is still scarce on indicators, which are largely represented by the indicators applicable to a manufacturing, narrower, scope (Ahi and Searcy, 2015). 


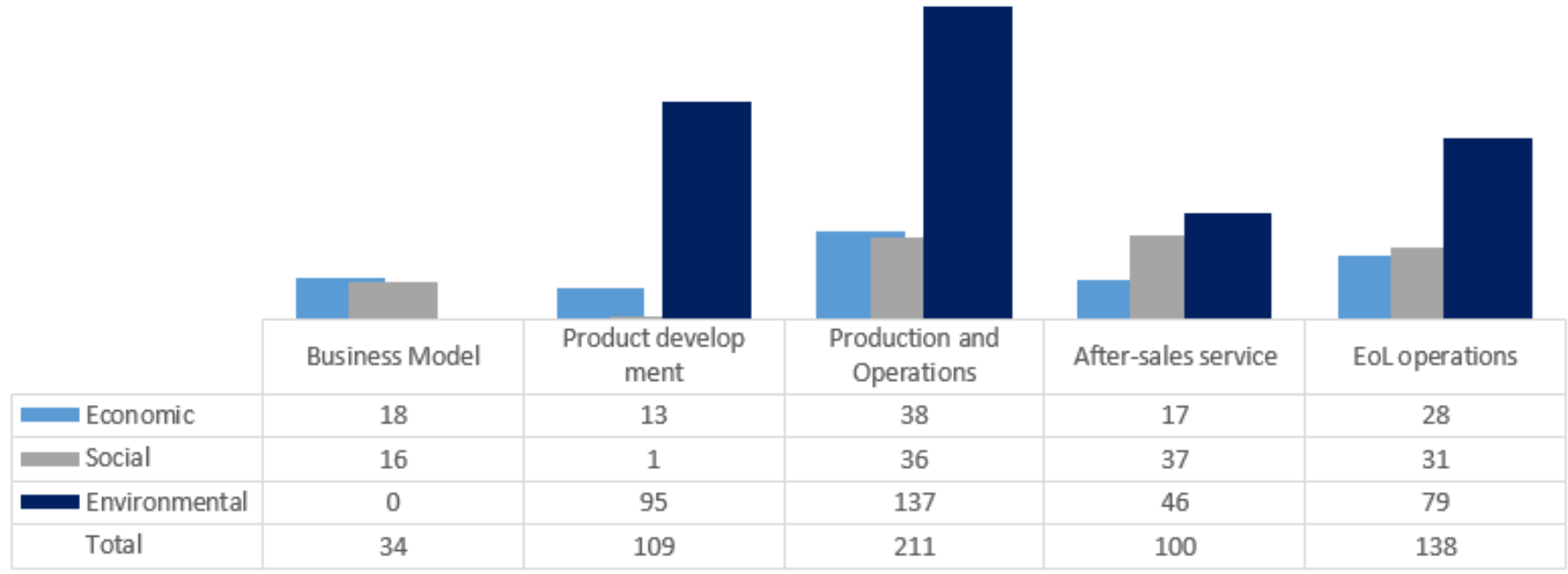

Fig. 7. Total number of performance indicators distributed according to business processes.

Similarly, the environmental dimension is well covered by performance indicators under 'product development', 'aftersales service' and 'EoL operations', while economic and social indicators are lagging behind. The abundancy of environmental indicators for 'product development' might be associated with a great consideration of eco-design principles in product development as well as applicability of life-cycle analysis for product impact assessment (Bhander et al., 2003; Fiksel and Wapman, 1994; Issa et al., 2015). Indicators suggested in the literature cover a range of aspects focused on: sustainable product 'behaviour' (Fiksel et al., 1998) with indicators such as 'power use during operation' and 'product disposition cost'; product end of life 'management' (Jiménez-Rivero and García-Navarro, 2016; Staikos and Rahimifard, 2007) with suggested indicators such as 'collection costs', 'refurbishing costs', 'unit energy price from energy recovery'; product development process with indicators suggested for each life cycle stage of a product (Arena et al., 2013; Issa et al., 2015; Okechukwu et al., 2014; Ussui, 2013).

While most of the 'product-related' publications acknowledged the importance of sustainability consideration during product development process, sustainability-related aspects were often reduced to environmental measurements, with little or no attention given to metrics capturing social performance, discerning to the 'intangible' and 'complex' nature of social aspects and their inter-relationships (von Geibler et al., 2006). Unsurprisingly, the social performance metrics is primarily concentrated on measuring affordability of a product (e.g. price) or to the product 'safety' (e.g. presence of toxic and hazardous materials) (Hallstedt, 2017; Lu et al., 2010), which is supported by the indicators retrieved in this study. Fig. 7. confirms literature and shows a striking imbalance of TBL dimensions for 'product development' BP, where only 1 indicator ('existence of product manual with environmental instructions') from social dimension was found to belong to, while number of environmental indicators are nine times the number of economic.

High occurrence of environmental indicators for 'after-sales services' and 'EoL operations' can be explained by 'repeated' indicators, i.e. product metrics being closely interconnected with production and post-production metrics, often linked to the life cycle thinking approach (Lu et al., 2010). For example, 'material amount' is considered in both, product development process and production and operations process (Badurdeen et al., 2015). Likewise, some indicators are mirrored between production and operations process and EoL operations; this is because remanufacturing process during EoL operations becomes a 'production' process for a remanufacturable product as well as recycling becomes 'production' process for a recyclable material (Atlee and Kirchain, 2006). This, consequently, implies that energy and materials need to be supplied for remanufacturing and recycling process as well as it entails workforce and transportation (Saavedra et al., 2013). 
Business model is the most poorly represented by performance indicators. Only 18 economic and 16 social indicators were extracted from the literature and applicable to a business model level, while environmental indicators were not recorded at all (Fig. 7). From all 52 publications used to retrieve performance indicators, only one publication addressed environmental metrics for business model (Watanabe et al., 2016), however after the publication was reviewed, the metrics suggested were found to be applicable to production level rather than business model level.

Important to note that many indicators could be affected by a decision during several business processes, therefore appear several times under different business processes. Refer to Table 1 for examples of performance indicators and their distribution according to business processes and aspects under TBL dimensions. The complete database of leading sustainability-related indicators is available for download following the address https://doi.org/10.11583/DTU.8034188.v1.

Table 1. Representative examples of performance indicators and their distribution according to business processes and triple bottom line dimensions and corresponding aspects.

\begin{tabular}{|c|c|c|c|c|}
\hline \multirow{2}{*}{$\begin{array}{l}\text { Business } \\
\text { Process }\end{array}$} & \multirow{2}{*}{ Performance Indicator } & \multicolumn{3}{|c|}{ Triple bottom line dimensions and corresponding aspects } \\
\hline & & Environmental & Social & Economic \\
\hline \multirow{5}{*}{ Business Model } & $\begin{array}{l}\text { - Revenues from refurbished } \\
\text { products }\end{array}$ & & & - Revenue \\
\hline & - Take-back offering for products & & - User relationship & \\
\hline & - Products consumed locally & & $\begin{array}{l}\text { - Community } \\
\text { relationship }\end{array}$ & \\
\hline & - Maintainable period after sales & & - User relationship & - Product quality \\
\hline & $\begin{array}{l}\text { - Cost of transportation in reverse } \\
\text { supply chain }\end{array}$ & - Energy consumption & & - Operational costs \\
\hline \multirow{6}{*}{$\begin{array}{l}\text { Product } \\
\text { Development }\end{array}$} & - First technical wear-out life & & & - Product quality \\
\hline & $\begin{array}{l}\text { - Existence of Manual with } \\
\text { environmental instructions }\end{array}$ & & - User relationship & \\
\hline & - Product Hazardous Materials & - Material safety & & \\
\hline & - Number of components & - Product architecture & & \\
\hline & - Amount of Conflict Resources (CR) & - Material consumption & $\begin{array}{l}\text { - Community } \\
\text { relationship }\end{array}$ & \\
\hline & - Packaging costs & & & - Operational costs \\
\hline \multirow{5}{*}{$\begin{array}{l}\text { Production and } \\
\text { Operations }\end{array}$} & - Total energy costs & & & - Operational costs \\
\hline & - Noise level at working station & & $\begin{array}{l}\text { - Employee health and } \\
\text { safety }\end{array}$ & \\
\hline & $\begin{array}{l}\text { - Suppliers without environmental, } \\
\text { health and safety standards }\end{array}$ & & - Supplier relationship & \\
\hline & - Intensity of transportation & - Energy consumption & & \\
\hline & $\begin{array}{l}\text { - Waste converted to Reusable } \\
\text { Material }\end{array}$ & $\begin{array}{l}\text { - Solid waste } \\
\text { generation }\end{array}$ & & \\
\hline \multirow{5}{*}{$\begin{array}{l}\text { After-sales } \\
\text { service }\end{array}$} & - Volume of chemicals and solvents & - Material consumption & & \\
\hline & - Efficiency of packaging design & - Material consumption & & \\
\hline & - Weight per Distance Travelled & - Energy consumption & & \\
\hline & - Consumer warranty cost & & & - Operational costs \\
\hline & $\begin{array}{l}\text { - Availability of customer support } \\
\text { option }\end{array}$ & & - User relationship & \\
\hline \multirow{4}{*}{$\begin{array}{l}\text { End of Life } \\
\text { operations }\end{array}$} & - Total sorting cost & & & - Operational costs \\
\hline & - Noise level at working station & & $\begin{array}{l}\text { - Employee health and } \\
\text { safety }\end{array}$ & \\
\hline & $\begin{array}{l}\text { - Energy consumption for } \\
\text { disassembly }\end{array}$ & - Energy consumption & & \\
\hline & - Replaced parts & - Material consumption & & \\
\hline
\end{tabular}




\subsection{Analysis of performance indicator classification according to Circular Economy strategies}

Classification of performance indicators according to CE strategies allows extracting sustainability-related indicators meaningful for the circular solution or configuration of solutions to be analysed in a specific case. Fig. 8 presents the results of indicator classification according to CE strategies used in this study. As seen in Fig. 8, the environmental dimension is dominating in indicator number for the majority of CE strategies, while the economic and social dimension differ depending on the CE strategy. The most covered by performance indicators CE strategy is 'reduce, restore and avoid impacts in manufacturing' with 193 indicators (69\% of the total number) capturing environmental dimension. Other CE strategies with a greater coverage by indicators are 'upgrade', 'repair and maintenance', 'refurbish', 'remanufacture' and 'recycle'. The CE strategy with least number of indicators is 'reinvent the paradigm'.

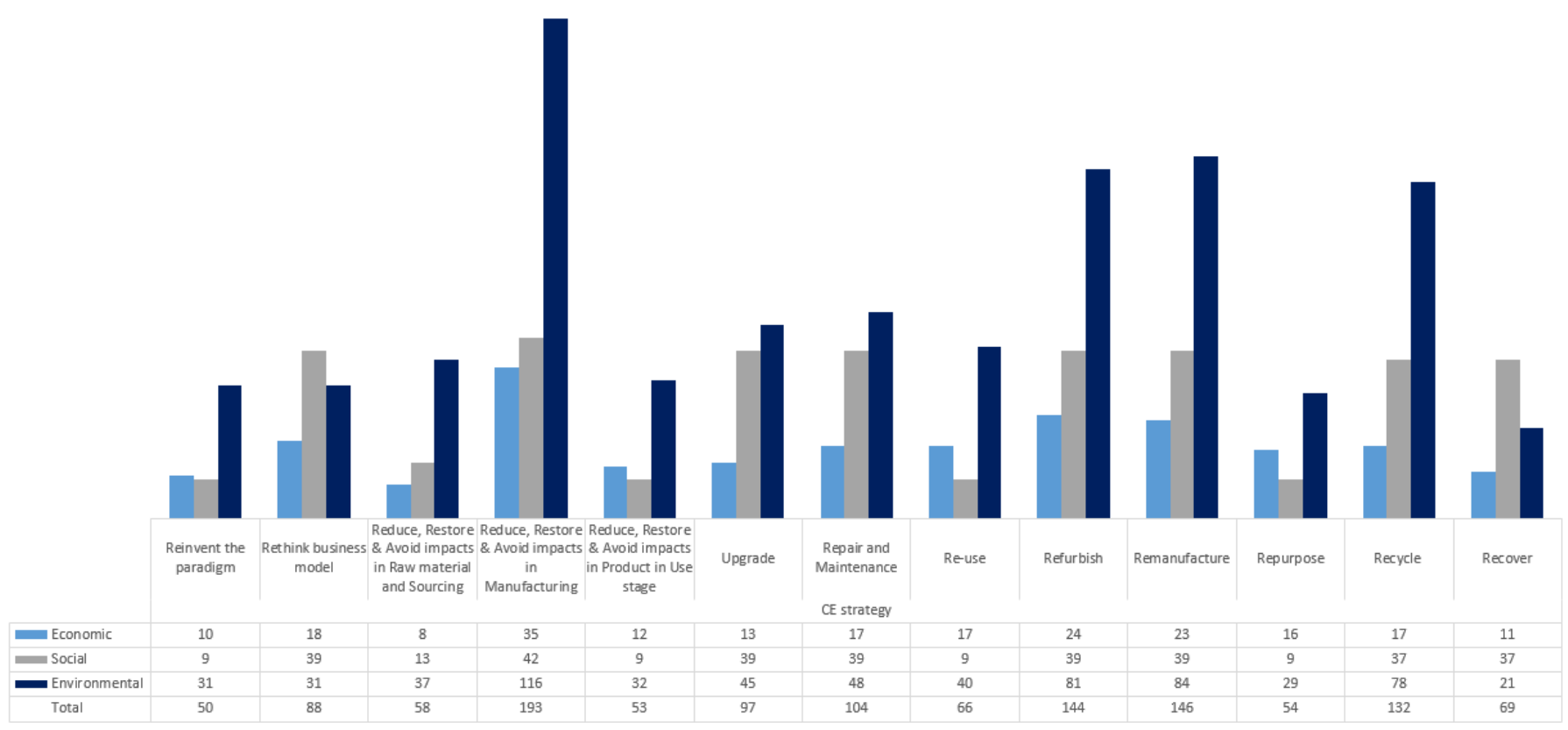

Fig. 8. Total number of performance indicators distributed according to Circular Economy strategies.

Environmental indicators' prevalence under the CE strategy 'reduce, restore and avoid impact in manufacturing' can be explained by correlation between nature and origin of indicators (environmental indicators coming from performance measurements in production and supply chain operations) and activity implied by this particular CE strategy (i.e. improving circularity potential and process efficiency in manufacturing process through consuming fewer natural resources or energy (e.g. pre-user recycling, material and energy efficiency, waste and emission treatment)). Analogous situation exists for the majority of CE strategies, where environmental indicators prevail over indicators from other dimensions (see Fig. 8 and Table 2). It can be elucidated that such distribution is well aligned with the 'activities' explicated by the majority of CE strategies (definitions of each CE strategy are summarized in Appendix B). Accordingly, CE strategy 'repair and maintenance' denotes activities that aim to restore faulty components of a defective product to return it to a functional state. This may require partial disassembly, hence usage of energy, materials, lubricants for the operation (Saavedra et al., 2013) and workforce to complete the task. Noteworthy, indicators devoted to capturing transportation and packaging aspects were assigned to the majority of CE strategies, as these aspects are important across strategies, i.e. mainly strategy-independent. 


\section{Journal Pre-proof}

Table 2. Representative examples of performance indicators and their distribution according to CE strategies and triple bottom line dimensions and corresponding aspects.

\begin{tabular}{|c|c|c|c|c|}
\hline \multirow{2}{*}{$\begin{array}{l}\text { Circular Economy } \\
\text { strategy }\end{array}$} & \multirow{2}{*}{ Performance Indicator } & \multicolumn{3}{|c|}{ Triple bottom line dimensions and corresponding aspects } \\
\hline & & Environmental & Social & Economic \\
\hline \multirow{3}{*}{ Reinvent the paradigm } & - First technical wear-out life & & & - Product quality \\
\hline & $\begin{array}{l}\text { - Availability of customer } \\
\text { support option }\end{array}$ & & - User relationship & \\
\hline & - Active functions & - Product architecture & & \\
\hline \multirow{3}{*}{ Rethink business model } & $\begin{array}{l}\text { - Materials used during after- } \\
\text { sales servicing of products }\end{array}$ & $\begin{array}{l}\text { - Material } \\
\text { consumption }\end{array}$ & & \\
\hline & - Spare Parts and Consumables & $\begin{array}{l}\text { - Material } \\
\text { consumption }\end{array}$ & & \\
\hline & $\begin{array}{l}\text { - Maintainable period after } \\
\text { sales }\end{array}$ & & - User relationship & - Product quality \\
\hline \multirow{3}{*}{$\begin{array}{l}\text { Reduce, restore \& avoid } \\
\text { impact in raw material } \\
\text { and sourcing }\end{array}$} & $\begin{array}{l}\text { - Suppliers that have completed } \\
\text { hazardous substances } \\
\text { information }\end{array}$ & & $\begin{array}{l}\text { - Supplier } \\
\text { relationship }\end{array}$ & \\
\hline & $\begin{array}{l}\text { - Fraction of Renewable Raw } \\
\text { Materials }\end{array}$ & $\begin{array}{l}\text { - Material } \\
\text { consumption }\end{array}$ & & \\
\hline & - Total material costs & & & - Operational costs \\
\hline \multirow{3}{*}{$\begin{array}{l}\text { Reduce, restore \& avoid } \\
\text { impact in raw } \\
\text { manufacturing }\end{array}$} & $\begin{array}{l}\text { - Cost of transportation during } \\
\text { Manufacturing }\end{array}$ & & & - Operational costs \\
\hline & - Vibration at working station & & $\begin{array}{l}\text { - Employee health } \\
\text { and safety }\end{array}$ & \\
\hline & $\begin{array}{l}\text { - Packaging materials from } \\
\text { suppliers }\end{array}$ & $\begin{array}{l}\text { - Material } \\
\text { consumption }\end{array}$ & & \\
\hline \multirow{3}{*}{$\begin{array}{l}\text { Reduce, restore \& avoid } \\
\text { impact in raw product } \\
\text { use \& operation }\end{array}$} & $\begin{array}{l}\text { - Cost of user education on use } \\
\text { and post-use opportunities }\end{array}$ & & & - Tactical costs \\
\hline & - Noise from product in use & - Energy consumption & & \\
\hline & $\begin{array}{l}\text { - Existence of Manual with } \\
\text { environmental instructions }\end{array}$ & & - User relationship & \\
\hline \multirow[t]{2}{*}{ Upgrade } & $\begin{array}{l}\text { - Laminated or Compound } \\
\text { Materials }\end{array}$ & $\begin{array}{l}\text { - Material } \\
\text { consumption }\end{array}$ & & \\
\hline & - Processing cost per unit & & & - Operational costs \\
\hline \multirow{2}{*}{ Repair \& maintenance } & $\begin{array}{l}\text { - Revenue from upgrade, repair } \\
\text { and maintenance services }\end{array}$ & & & - Revenue \\
\hline & $\begin{array}{l}\text { - Specific Energy Consumption } \\
\text { in operations }\end{array}$ & - Energy consumption & & \\
\hline \multirow[t]{2}{*}{ Reuse } & $\begin{array}{l}\text { - Fraction of Reused } \\
\text { Components }\end{array}$ & $\begin{array}{l}\text { - Material } \\
\text { consumption }\end{array}$ & & \\
\hline & - Total acquisition cost & & & - Operational costs \\
\hline \multirow{4}{*}{ Refurbish } & $\begin{array}{l}\text { - Cost of non-destructive } \\
\text { disassembly (CND) }\end{array}$ & & & - Operational costs \\
\hline & $\begin{array}{l}\text { - Energy consumption for } \\
\text { disassembly }\end{array}$ & - Energy consumption & & \\
\hline & - Product Solid Waste Fraction & $\begin{array}{l}\text { - Solid waste } \\
\text { generation }\end{array}$ & & \\
\hline & $\begin{array}{l}\text {-Mist/dust level at working } \\
\text { stations }\end{array}$ & & $\begin{array}{l}\text { - Employee health } \\
\text { and safety }\end{array}$ & \\
\hline \multirow{3}{*}{ Remanufacture } & $\begin{array}{l}\text { - Cost of transportation in } \\
\text { reverse supply chain }\end{array}$ & & & - Operational costs \\
\hline & $\begin{array}{l}\text { - Exposure to corrosive/toxic } \\
\text { chemicals }\end{array}$ & & $\begin{array}{l}\text { - Employee health } \\
\text { and safety }\end{array}$ & \\
\hline & - Fraction of Reused & - Material & & \\
\hline
\end{tabular}


Journal Pre-proof

\begin{tabular}{|c|c|c|c|}
\hline & Components & consumption & \\
\hline \multirow{2}{*}{ Repurpose } & - Active functions & - Product architecture & \\
\hline & - Product Hazardous Materials & - Material safety & \\
\hline \multirow{4}{*}{ Recycle } & - Cost of recycling & & - Operational costs \\
\hline & $\begin{array}{l}\text { - Transportation cost from } \\
\text { facility to recycling plant }\end{array}$ & & - Operational costs \\
\hline & $\begin{array}{l}\text { - Waste converted to Reusable } \\
\text { Material }\end{array}$ & $\begin{array}{l}\text { - Solid waste } \\
\text { generation }\end{array}$ & \\
\hline & - Specific Water Consumption & - Water consumption & \\
\hline \multirow{3}{*}{ Recover } & - Load mode of transport & - Energy consumption & \\
\hline & $\begin{array}{l}\text { - Energy generated with process } \\
\text { streams }\end{array}$ & - Energy consumption & \\
\hline & - Cost of disposal & & - Operational costs \\
\hline
\end{tabular}

While most of the CE strategies seem to be unequivocal in what they entail based on their definitions, the CE strategy 'reinvent the paradigm' and 'rethink business model' might need a detailed elaboration on what they necessitate. 'Reinvent the paradigm' concerns smarter business concepts that promote resource decoupling, thus making a focus on offering dematerialized and/or multifunctional solutions (Appendix B). This strategy requires a shift towards a 'radical' reinvention of products supported by technology and infrastructure (e.g. dematerialized solution offered by Spotify as opposed to a CD) (Potting et al., 2017). Therefore, the environmental indicators capturing this CE strategy address resource consumption (aligned with resource decoupling) for producing and offering such solution; the social indicators address user relationships and the economic indicators address mostly operational costs and quality of products (Table 1). The CE strategy 'rethink business model' advocates shift of value offering from selling products to selling access and performance enabled by product-service system (PSS) business models. The products may not radically change, however the relationship between customer/user and the product changes (e.g. product ownership is retained by the manufacturer or service provider and the customer pays to have access to the product, like in a bike sharing model) (Potting et al., 2017). The environmental indicators for this CE strategy address aspects of material consumption during service provision or use of a PSS solution, while the economic indicators address operational costs and revenues. Social indicators dominate, capturing performance on user and provider aspects, complemented by metrics on local communities and other stakeholders. Examples of social indicators under this CE strategy are 'programs to enhance community health or safety', 'purchase of locally produced and offered goods and services', which cover aspects of local communities, as an example. Several publications extracted from the literature review concerned sustainable development and measurement of PSS solutions (Chou et al., 2015; Hu et al., 2012; Sousa-Zomer and Cauchick Miguel, 2015; Xing et al., 2013). Important attention is given to the social dimension that should comprise indicators addressing user aspects (Sousa-Zomer and Cauchick Miguel, 2015). This may provide a basis for more work on consolidation of usercentric indicators for PSS measurements, hence being applicable to CE strategy 'rethink business model'.

\section{Discussion}

The analysis presented above has highlighted several fundamental issues that provide an important perspective on the contribution of this article. First, the number of papers that satisfied the inclusion criteria in the systematic literature review constituted to only $2.5 \%$ of the total number of publications retrieved from the two search databases. Considering the inclusion of business processes into the search strings, it can be concluded that the rejected publications either proposed lagging indicators as sustainability performance measures or did not propose any indicators at all. These findings are in line with claims about the lack of consideration of leading indicators to support decision-making, including sustainability decision-making (Morioka et al., 2016; Morioka and Carvalho, 2016). Lagging indicators are widely employed by different assessments, e.g. environmental life cycle assessment (climate change indicator), business performance assessments (gross margin indicator) or organizational performance assessments (customer retention indicator) (Arena et al., 2013; Pojasek, 2009). While lagging indicators are essential for corporate reporting, as they 
indicate the performance and are generally applicable across the sectors, the caveat about using lagging indicators is that they might not indicate where to focus on to improve the performance (Epstein and Roy, 2001).

Second, there is a challenge directly related to the ambiguity of use of the term 'sustainability' in the manufacturing context, which is often reduced to environmental considerations. The results of this review highlight the prevalence of environmental indicators over economic and social, which is confirmed by the literature (Ahi and Searcy, 2015; Joung et al., 2013). This might be attributed, firstly, to the focus of the research dominating the sustainability field over the past 30 years. Since the release of the Brundtland Report in 1987, calling to pursue sustainable development, manufacturing industries began exploring tools and techniques to conduct sustainable manufacturing (Veleva and Ellenbecker, 2001). The goal then consisted of not only achieving and measuring the business success, but also finding a logic to measure progress towards triple-bottom line advancements. Secondly, many governments enacted regulations requiring manufacturing companies to track and report on many aspects on their environmental impacts (Ahi and Searcy, 2015). As a result, performance measurement systems included environmental indicators related to 'internal' operations, tracking energy, material, and water consumption and waste generation, which unquestionably reflected the efficiency of internal processes (Shahbazi et al., 2018). An interesting observation can be recorded in relation to indicators used in supply chain measurements. Ahi and Searcy (2015) made a comprehensive review of performance metrics used in sustainable supply chain (including supplier, manufacturer, distributor and retailer dimensions) measurements, reporting on the dominance of environmental indicators, followed by economic and lastly by social indicators. Indicators reviewed in their study showed that, despite of the supply chain focus, most of the indicators aligned with productionrelated indicators, such as 'total material consumption', 'amount of waste generated', etc. This uniform applicability of indicators can be explained by a 'focal company' view - a company that is in control of design of products and services offered (i.e. the brand owner), however with production processes situated elsewhere in supply chain. Focal companies, therefore, tend to govern a supply chain to ensure the brand reputation is uncompromised due to unsustainable behaviour (Reefke and Trocchi, 2013). The divergence of definitions of supply chain and its boundaries elucidate a substantial confusion when searching for indicators addressing supply and distribution side of production. While larger focus on environmental aspects and impacts is definitely a positive implication, interchangeability between terms 'environmental' and 'sustainable' could lead to a 'simplification' of sustainability. Furthermore, a mass of publications revealed confusion in terms of inconsistent nomenclatures and indicator definitions per se, suggesting 'customer satisfaction' or 'increased safety' as indicators while the former is a dimension of performance and latter is merely an objective or goal to be achieved.

Despite the prevalence of the environmental dimension and a broad range of aspects addressed under it, none of the retrieved indicators covered the 'land use' aspect, and only one indicator covered 'soil pollution' aspect. These categories could be important to address from perspective of manufacturing actors belonging to bio-economy sector, i.e. industries that use biological resources from land and sea to produce, for example, food (European Commission, 2018).

There is clear asymmetry between the TBL dimensions covered by indicators. The social dimension is underrepresented by indicators, which mostly capture 'internal' matters, such as employee empowerment and employment conditions. This could be due to the fact, that 'internal' social aspects are more 'quantifiable', with indicators 'overtime work', 'temperature level at working stations' and 'employee health and safety training hours' lending some credence to this argument. 'External view' indicators capture social aspects, such as community, supplier-user relationships, however are low in numbers, especially in the user related aspect. This can be due to a 'qualitative' nature of 'external' aspects, often difficult to measure objectively. Considering the importance of users and communities in the CE context, who are seen as enablers of CE (Kirchherr et al., 2017), it may be necessary to include metrics addressing community and user relationships devoted to, for example, quality of life as well as user privacy. 
In relation to economic indicators, there is an evident preference for measuring cost-related aspects, such as operational and tactical costs ('energy cost in manufacturing', 'total holding costs', 'material cost per unit of product', etc.), which can be explained by, in part, wider focus on efficiency (i.e. eco-efficiency) and cost minimization in manufacturing industry (Joung et al., 2013), but also by being a natural part of accounting and cost-benefit assessments. Likewise, it may be pointed out that there is a need to address the development of economic indicators capturing the user perspective (e.g. costs and revenues), which again are important in the CE context, as users become more active players in the system by delivering value back (Haase et al., 2017; Xing et al., 2013).

The results of classification of indicators according to business processes revealed several shortcomings. Despite the availability of indicators capturing all three TBL dimensions, there is a lack of indicators available for the use during product development and business model development processes. As for the product development process, environmental indicators are dominant and reported mostly on by the literature from eco-design and life cycle community (Arena et al., 2013; Fiksel et al., 1998; Issa et al., 2015). This can be explained by the evidence that product design stage is a critical time for addressing environmental, social and economic impacts of a product during its all life cycle stages (McAloone and Pigosso, 2018); therefore, sustainability-related indicators can support designers in assessing the potential sustainability performance of the product prior to its production and subsequent utilization. Environmental indicators available for product development are largely devoted to measuring material type and consumption, resource consumption, waste and pollution generation, and physical properties and attributes of products (i.e. product architecture) (Badurdeen et al., 2015; Hallstedt, 2017). Issa et al. (2015) made a comprehensive review of leading environmental product-related indicators, which were collected in a database and classified according to life cycle stages and environmental aspects. The aim of their study was to support product developers to implement ecodesign in a measurable way. Contrariwise, social indicators are scarce for the product development process, with only few studies addressing the social dimension by proposing checklists or guiding questions to be deployed during product development process (Hallstedt, 2017). There is clear need to develop and introduce social indicators (qualitative and quantitative) that can be used during product development process in order to ensure three-dimensional consideration of sustainability.

As for business model development, the total number of indicators are deficient. While economic and social dimensions are equally covered, environmental indicators are non-existent. Various publications focus on designing business models for sustainability that often rest on the notions of creating significant positive environmental and social impacts while maximizing values for all stakeholders (Bocken et al., 2014; Lüdeke-Freund, 2010), however propositions of how to measure potential sustainability contribution of such business models are still lacking (Evans et al., 2017). Lack of explicit indicators for the business model level can be justified by a relatively recent deployment of business model as a term (Wirtz et al., 2016), with scattered identification of what dimensions a business model should consist of and what its main features are. Pieroni et al. (2019) report that decision-making during business model development mostly relies on qualitative data. Availability of sustainability indicators (qualitative and quantitative) is fundamental in the business model design stage to ensure that a company assesses value for sustainability (through operations, products or both) (Ludeke-Freund et al., 2017).

The results of the classification of indicators according to CE strategies revealed several patterns. Firstly, most CE strategies (e.g. 'reduce, restore and avoid impacts in: - raw material and sourcing; -manufacturing; - product in use stage'; upgrade', 'repair and maintenance', 're-use', 'refurbish', 'remanufacture', 'repurpose', 'recycle' and 'recover') have a fair alignment between activities they explicate and indicators for performance measurement of those activities. For example, the indicator 'energy consumption for disassembly' addresses the activity explicated by the CE strategies 'refurbish', 'remanufacture, and 'recycle'; while the indicator 'first wear-out life' addresses the aspects explicated by the CE strategies 'reinvent the paradigm', 'rethink business model', and 'reduce, restore and avoid impacts in product in use 
stage'. Environmental indicators prevail for the majority of CE strategies due to the overall dominance of environmental indicators extracted from the literature.

Noteworthy, CE strategies with focus on product use (i.e. 'reinvent the paradigm', 'reduce, restore and avoid impacts in product in use stage', 're-use', and 'repurpose') are scarce on social indicators, despite the importance of the user's role and impact during use of and interaction with a product. At the same time, there is a reasonable coverage by social indicators for CE strategies 'rethink business model', 'reduce, restore and avoid impacts in manufacturing', 'upgrade', 'repair and maintenance', 'refurbish', 'remanufacture', 'recycle' and 'recover'. This might be attributed to the fact that the activities explicated by those strategies are labour-intensive, therefore, social indicators capture employee-related aspect to a wider extent than, for example, strategies explicating use of a product ('re-use'). As discussed in Section 4.4., the CE strategy 'rethink business model' advocates shift of value offering from selling products to selling access and performance enabled by product-service system (PSS) business models. Therefore, is it important to capture different aspects of a PSS offering, such as 'behaviour' of a product in a PSS, material and energy consumption and costs associated with the provision of a PSS (Elia et al., 2017; Kjaer et al., 2018). The findings reveal that the CE strategy 'rethink business model' is well captured by environmental and social indicators that could allow verifying the effectiveness of a PSS solution; however, this may need to be complemented by more indicators addressing the economic dimension.

In order to evaluate whether the retrieved indicators are sufficient for sustainability assessment of CE initiatives, it is important to apply indicators that are suitable for a combination of business processes and CE solutions. Therefore, this research is a first attempt to propose the assessment of the potential sustainability performance of CE strategies in the early decision-making stage and is mainly differentiated by: (i) its focus on leading indicators; (ii) the consideration of the TBL approach: (iii) the emphasis on primary business processes that are typical for any manufacturing company; (iv) the consideration of variety of CE strategies applicable in a manufacturing context. The summary of key findings identified in the study are presented in Table 3.

Table 3. Summary of the key findings identified through the study.

\begin{tabular}{|l|l|}
\hline Research area & Key findings \\
\hline $\begin{array}{l}\text { Sustainability performance } \\
\text { indicators }\end{array}$ & $\begin{array}{l}\text { - There is a need for a wider deployment of leading performance indicators in sustainability } \\
\text { assessments. Leading indicators offer useful information about the potential sustainability } \\
\text { performance of a solution, thus are effective for early decision-making and management of } \\
\text { processes. }\end{array}$ \\
\hline $\begin{array}{l}\text { Environmental dimension of } \\
\text { sustainability }\end{array}$ & $\begin{array}{l}\text { - Land use oriented and soil pollution indicators are non-existent. This category of indicators } \\
\text { is crucial to address from the perspective of manufacturing actors from bio-economy sector } \\
\text { (e.g. using biological resources for food production). }\end{array}$ \\
\hline Social dimension of sustainability & $\begin{array}{l}\text { - Indicators for social dimension are scarce and mostly focus on "internal" stakeholder groups } \\
\text { (i.e. employees). Indicators capturing "user-related" and "community relationships" aspects } \\
\text { should be expanded, as they are crucial considering the role of users and communities as } \\
\text { enablers of Circular Economy. }\end{array}$ \\
\hline $\begin{array}{l}\text { Sustainable Business Model } \\
\text { support }\end{array}$ & $\begin{array}{l}\text { - Indicators capturing environmental performance are non-existent for business model level. } \\
\text { Availability of sustainability indicators (qualitative and quantitative) is fundamental in } \\
\text { business model design stage to ensure a company can create value for sustainability (through } \\
\text { operations, products or both). }\end{array}$ \\
\hline Sustainable Product & \begin{tabular}{l} 
- Social indicators are non-existent for product development level. In order to operationalize \\
\hline
\end{tabular}
\end{tabular}




\begin{tabular}{|l|l|}
\hline Development support & $\begin{array}{l}\text { corporate sustainability objectives, product development techniques and tools should } \\
\text { incorporate three sustainability dimensions simultaneously to be used by designers. }\end{array}$ \\
\hline Circular Economy $\begin{array}{l}\text { Circular Economy } \\
\text { manufacturing context. While some CE strategies seem to be unequivocal in what they entail } \\
\text { (e.g. 'reduce impact in manufacturing'), other CE strategies might need a detailed } \\
\text { elaboration on what they necessitate (e.g. 'reinvent the paradigm'). }\end{array}$ & $\begin{array}{l}\text { - Leading sustainability-related performance indicators are available for a wide range of } \\
\text { Circular Economy strategies: } \\
\text { - distribution and nature of indicators is aligned with the 'activities' explicated by the CE } \\
\text { strategies } \\
\text { - availability of indicators makes it possible to extract the indicators meaningful to the } \\
\text { circular solution(s) in focus. } \\
\text { - Indicator classification according to CE strategies and business process allows the } \\
\text { configuration of different combinations of circular solutions to be exploited in various } \\
\text { business processes, thus displaying a suitable set of sustainability performance indicators } \\
\text { relevant for business and/or operational levels. }\end{array}$ \\
\hline
\end{tabular}

\section{Conclusions}

This research aimed to identify and systematize leading performance indicators that could be used to measure the potential sustainability performance of CE strategies, in order to support decision-making process in manufacturing industry. The research methodology was rationalized by a systematic literature review with the goal of identification and collection of leading performance indicators covering environmental, economic and social dimensions for a range of business processes. As a result, identified publications were critically assessed and 279 leading performance indicators were extracted and systematized in a database, with consequent classification according to: TBL dimensions and their related aspects; business processes; and CE strategies. This classification allows the configuration of different combinations of circular solutions to be exploited in various business processes, thus displaying a suitable set of sustainability performance indicators to be measured early in the decision-making stage. All the indicators available in the repository have their name, detailed description, formula, unit of measurement, and purpose of measurement registered.

The main findings of this research are: (i) sustainability assessments often rely on lagging indicators, which may not provide the exact indication for practitioners on where to make an improvement; (ii) sustainability performance indicators frequently measure 'internal' company's affairs: cost, eco-efficiency and social matters; (iii) the environmental dimension is the most covered by indicators; (iv) product development is well represented by product-related performance indicators, the majority of which are environmental indicators, while social indicators are scarce; $(v)$ there is a lack of indicators to support decision-making during the business model development process, with indicators for environmental dimension being non-existent; (vi) there are suitable sustainability indicators for each CE strategy adopted in this study.

By systematizing a comprehensive database of leading sustainability-related performance indicators, the research offers contributions to: (i) academia - by proposing to advance discussions towards a wider inclusion of leading indicators into sustainability assessments as well as to proceed with indicator developments; (ii) industry - by providing a set of leading performance indicators to be deployed in decision making during various business processes and for CE strategies. We assert that leading performance indicators provide a better insight into strengths and weaknesses of the circular solution thus would enable more informed and balanced decision-making for sustainability. 
Some limitations of this research can be pointed out. Firstly, the indicators were extracted directly from the academic literature without consulting the 'grey' literature sources and practitioners' archives. This limitation can be addressed by expanding the search scope to include corporate surveys and 'grey' source databases. Secondly, the CE strategies framework modified from Potting et al. (2017) served as one of the indicator classification criteria. Use of the CE strategy framework has guided the authors in the classification logic, largely affected by the number of strategies chosen in the framework as well as the descriptions of what they entail. It is apparent that utilization of any other CE strategy framework would lead to a different distribution of performance indicators. Finally, usage of a straightforward TBL approach for indicator classification may possess the risk of separating the indicators rather than integrating them for a holistic interpretation of sustainability. We do, however, acknowledge that most indicators capture cross-dimensional concerns (e.g. socioeconomic issues of supplier selection), which may be investigated by finding interdependencies between indicators in future research.

This study is a first step to identify and classify leading sustainability related-indicators according to business processes and CE strategies. We assert that transforming to CE is a complex process that requires thoughtful planning and evaluation, which necessitates the ability of decision makers to have better insights into organisational processes and circular solutions that will most likely contribute to sustainability. Leading performance indicators should be viewed as carriers of useful and measurable information to support the process of decision-making under complex circumstances. In order to effectively capture and measure the potential sustainability performance of CE strategies, it is important to aid the identification of the core performance indicators suitable for a particular CE solution or a combination of thereof during a particular business process. The database of performance indicators is a first building block of a foundation for sustainability screening framework that also comprises the procedure for a systematic indicator selection and procedure for decision-making for sustainability in a CE context. Therefore, the next step within the frame of this research is to develop a framework for a systematic indicator selection, to facilitate meaningful application in industry. The proposed approach will subsequently be tested with actors from manufacturing companies, to identify the usefulness of the proposed indicators and usability of the selection procedure. This study is a part of a broader research activity, aimed at developing a framework to support early decision-making for CE with a holistic sustainability consideration. This support framework should underpin the universal yet context-dependent and transdisciplinary nature of sustainability, with CE as promising means to reinforce the sustainability pursuit.

\section{Acknowledgements}

This article is one of the outcomes of the research project CIRCit (Circular Economy Integration in the Nordic Industry for Enhanced Sustainability and Competitiveness), which is part of the Nordic Green Growth Research and Innovation Programme (grant number: 83144), jointly supported by NordForsk, Nordic Energy Research, and Nordic Innovation. The authors would like to thank the CIRCit consortium partners for enriching discussions about CE and sustainability. 


\section{Appendix A}

Search strings consisting of the key words used in Scopus and Web of Science

\begin{tabular}{|c|c|}
\hline $\begin{array}{l}\text { All in all the search string in Scopus is as presented and results } \\
\text { in } \\
\mathbf{5 2 1} \text { documents }\end{array}$ & $\begin{array}{l}\text { All in all the search string in Web of Science is as } \\
\text { presented and results in } \\
\mathbf{1 4 5} \text { documents }\end{array}$ \\
\hline 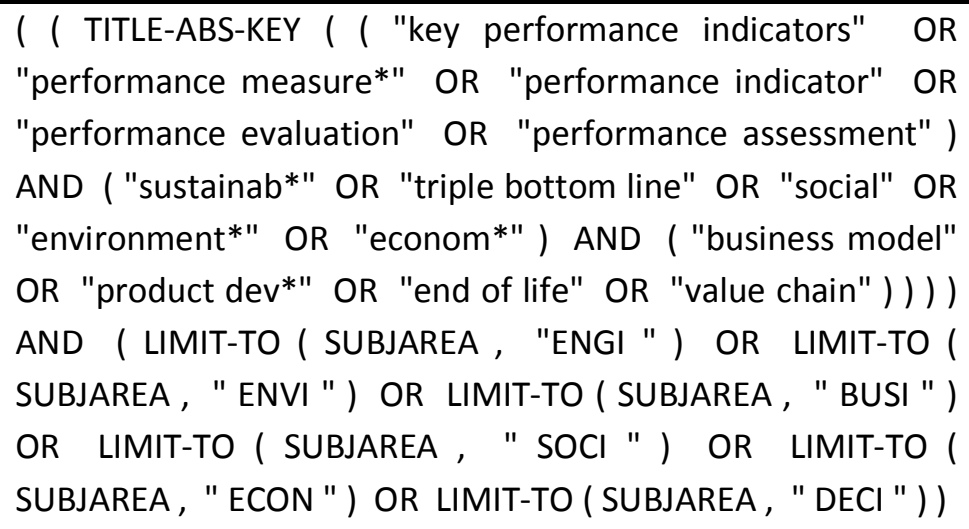 & $\begin{array}{l}\text { TI=(key performance indicators } O R \text { indicator } O R \\
\text { metric } O R \text { index } O R \text { indices } O R \text { measure* } O R \\
\text { assessment } O R \text { evaluation) } A N D T I=(\text { sustainab* } O R \\
\text { triple bottom line OR environment* OR social OR } \\
\text { economic) AND } \mathrm{Tl}=\text { (business model OR product } \\
\text { development OR "end of life" OR value chain) }\end{array}$ \\
\hline
\end{tabular}

\section{Appendix B}

Circular Economy strategies: the list of strategies used for indicator classification and their definitions. Source: modified from Potting et al. (2017)

\begin{tabular}{l|l}
$\begin{array}{l}\text { Reinvent the } \\
\text { paradigm }\end{array}$ & $\begin{array}{l}\text { - can be seen as the one of a radical type, with practices that advise striving for full decoupling of } \\
\text { resources by "reinventing" the production and consumption patterns. Here the business is } \\
\text { centered on providing the same function or combined functions to the customers, often enabled } \\
\text { by radically different products (virtualized multifunctional non-physical), technology or both. }\end{array}$ \\
$\begin{array}{l}\text { Furthermore, the focus can also be on promoting sufficiency, e.g. promoting moderate } \\
\text { consumption through education and consumer engagement. } \\
\text { (Potting et al., 2017) }\end{array}$ \\
\hline $\begin{array}{l}\text { Rethink } \\
\text { business model }\end{array}$ & $\begin{array}{l}\text { - a strategy that focuses on making product use more intensive by rethinking the way of } \\
\text { delivering the function and/or value proposition (e.g.: performance or access based models, } \\
\text { sharing platforms). Products tend to not radically change, although the technology can evolve. } \\
\text { (Bakker et al., 2014; Bocken et al., 2016) }\end{array}$ \\
\hline $\begin{array}{l}\text { Reduce, restore } \& \text { avoid impact } \\
\text { in Raw material } \\
\text { and Sourcing }\end{array}$ & $\begin{array}{l}\text { - a strategy that aims at reducing, restoring and avoiding impacts in raw material and sourcing. } \\
\text { as: renewable, recyclable material; materials from secondary source sourcing (recycled materials, } \\
\text { Industrial Symbiosis); restorative sourcing (use of materials previously designated as 'waste' as } \\
\text { input, e.g. waste re-mining from landfill or using ocean plastics); use of non-toxic or benign } \\
\text { materials; use of the lowest suitable grade of materials suitable for the application. } \\
\text { (Lieder and Rashid, 2016) }\end{array}$ \\
\hline $\begin{array}{l}\text { Reduce, restore } \\
\text { \& avoid impact }\end{array}$ & $\begin{array}{l}\text { - a strategy that aims at improving circularity potential and process efficiency in product } \\
\text { manufacture through: consuming fewer natural resources or energy, appropriate treatment of }\end{array}$ \\
\hline
\end{tabular}




\begin{tabular}{|c|c|}
\hline $\begin{array}{l}\text { in } \\
\text { Manufacturing }\end{array}$ & $\begin{array}{l}\text { emissions and waste, recycling and reusing wastes and scrap on site (pre-consumer, or interna } \\
\text { recycling and reuse), recovery of energy and nutrients; eco-friendly transport and driving. } \\
\text { (Lieder and Rashid, 2016) }\end{array}$ \\
\hline $\begin{array}{l}\text { Reduce, restore } \\
\text { \& avoid impact } \\
\text { in Product in } \\
\text { Use }\end{array}$ & $\begin{array}{l}\text { - a strategy aiming at improving circularity potential and efficiency in product use and operation } \\
\text { through: wiser use and operation of products (usually enabled by data technologies: tracking, } \\
\text { sensors), efficient resource consumption during operation (energy, water, consumables). } \\
\text { (Lieder and Rashid, 2016) }\end{array}$ \\
\hline $\begin{array}{l}\text { Recirculate } \\
\text { products and } \\
\text { parts by: } \\
\text { - Upgrade }\end{array}$ & $\begin{array}{l}\text { - a strategy aiming at extending existing use cycle by adding value or enhancing the function of a } \\
\text { product in respect to previous versions (can involve aesthetic or functional upgrades which } \\
\text { usually do not involve disassembly). For the purpose of the tool, the upgrade implies } \\
\text { returning/keeping the product at the original user. } \\
\text { (Parkinson and Thompson, 2003) }\end{array}$ \\
\hline $\begin{array}{l}\text { Recirculate } \\
\text { products and } \\
\text { parts by: } \\
\text { - Repair and } \\
\text { maintenance }\end{array}$ & $\begin{array}{l}\text { - a strategy aiming at extending existing use cycle by countering wear and tear, and correcting } \\
\text { faulty components of a defective product/part to return it to its original functionality. The } \\
\text { process may require partial disassembly, cleaning, and inspection. For the purpose of the tool, } \\
\text { the repair and maintenance implies returning/keeping the product at the original user. } \\
\text { (Thierry et al., 1995) }\end{array}$ \\
\hline $\begin{array}{l}\text { Recirculate } \\
\text { products and } \\
\text { parts by: } \\
\text { - Reuse }\end{array}$ & $\begin{array}{l}\text { - a strategy aiming at extending to new use cycle by reusing a part/product (discarded/ not in } \\
\text { use) that is still in good condition and can fulfil its original function in a different use context } \\
\text { (new customer/user). Before the part/product is offered for reuse, it may involve a minimum } \\
\text { amount of condition monitoring such as cleaning or repackaging. No warranties are provided and } \\
\text { no disassembly is involved). } \\
\text { (ljomah, 2009) }\end{array}$ \\
\hline $\begin{array}{l}\text { Recirculate } \\
\text { products and } \\
\text { parts by: } \\
\text { - Refurbish }\end{array}$ & $\begin{array}{l}\text { - a strategy aiming at extending to new use cycles by returning a part/ product (discarded/ not in } \\
\text { use) to a satisfactory working condition that may be inferior to the original specification. } \\
\text { Refurbishing may involve: cleaning, partial disassembly, repairing, resurfacing, repainting, re- } \\
\text { sleeving. } \\
\text { (Saavedra et al., 2013) }\end{array}$ \\
\hline $\begin{array}{l}\text { Recirculate } \\
\text { products and } \\
\text { parts by: } \\
\text {-Remanufacture }\end{array}$ & $\begin{array}{l}\text { - a strategy aiming at extending to new use cycles by returning a product (discarded/ not in use) } \\
\text { to at least Original Equipment Manufacturer (OEM) performance specification and quality. } \\
\text { Remanufacturing normally is more rigorous and costly than refurbishment and involves total } \\
\text { disassembly and reassembly. In the case of traditional product sales, a warranty that is at least } \\
\text { equal to that of a newly manufactured equivalent may be issued). } \\
\text { (Saavedra et al., 2013) }\end{array}$ \\
\hline $\begin{array}{l}\text { Recirculate } \\
\text { products and } \\
\text { parts by: }\end{array}$ & $\begin{array}{l}\text { - a strategy aiming at extending to new use cycles by using a product (discarded/not in use) or its } \\
\text { parts for different functions. Before the part/product is offered for repurpose, it may involve a } \\
\text { minimum amount of condition monitoring such as cleaning or repackaging. }\end{array}$ \\
\hline
\end{tabular}




\begin{tabular}{|l|l|}
\hline - Repurpose & (Reike et al., 2018) \\
\hline $\begin{array}{l}\text { Recirculate } \\
\text { materials by: }\end{array}$ & $\begin{array}{l}\text { - a strategy aiming at extending material lifespan by processing them in order to obtain the same } \\
\text { or comparable quality of material to be applied back in the industrial processes. In this } \\
\text { framework recycling concerns recycling of materials coming from used products, e.g. post- } \\
\text { consumer recycling as opposed to pre-consumer recycling done in manufacturing stage. } \\
\text { (Allwood et al., 2011) }\end{array}$ \\
\hline $\begin{array}{l}\text { Recirculate } \\
\text { materials by: }\end{array}$ & $\begin{array}{l}\text { - a strategy aiming at recovering energy or nutrients from composting or processing materials } \\
\text { (e.g. incineration of combustible waste, pyrolysis, anaerobic digestion or composting to recover } \\
\text { biological nutrients. } \\
\text { - Recovery }\end{array}$ \\
\hline
\end{tabular}




\section{References}

Adriaanse, L.S., Rensleigh, C., 2013. Web of Science, Scopus and Google Scholar: A content comprehensiveness comparison. Electron. Libr. 31, 727-744. https://doi.org/10.1108/EL-12-2011-0174

Agrawal, V. V., Ferguson, M., Toktay, L.B., Thomas, V.M., 2012. Is Leasing Greener Than Selling? Manage. Sci. 58, 523533. https://doi.org/10.1287/mnsc.1110.1428

Ahi, P., Searcy, C., 2015. An analysis of metrics used to measure performance in green and sustainable supply chains. J. Clean. Prod. 86, 360-377. https://doi.org/10.1016/j.jclepro.2014.08.005

Allwood, J.M., Ashby, M.F., Gutowski, T.G., Worrell, E., 2011. Material efficiency: A white paper. Resour. Conserv. Recycl. 55, 362-381. https://doi.org/10.1016/j.resconrec.2010.11.002

Amrina, E., Yusof, S.M.M., 2011. Key performance indicators for sustainable manufacturing evaluation in automotive companies. Ind. Eng. Eng. Manag. (IEEM), 2011 IEEE Int. Conf. 1093-1097. https://doi.org/10.1109/IEEM.2011.6118084

Arena, M., Azzone, G., Conte, A., 2013. A streamlined LCA framework to support early decision making in vehicle development. J. Clean. Prod. 41, 105-113. https://doi.org/10.1016/j.jclepro.2012.09.031

Atlee, J., Kirchain, R., 2006. Operational sustainability metrics assessing metric effectiveness in the context of electronics-recycling systems. Environ. Sci. Technol. 40, 4506-4513. https://doi.org/10.1021/es050935।

Azapagic, a., Perdan, S., 2000. Indicators of sustainable development for industry: a general framework. Trans IChemE 78, 243-261. https://doi.org/10.1205/095758200530763

Badurdeen, F., Shuaib, M.A., Lu, T., Jawahir, I.S., 2015. Sustainable Value Creation in Manufacturing at Product and Process Levels: Metrics-Based Evaluation, in: Handbook of Manufacturing Engineering and Technology. SpringerVerlag, London, pp. 3343-3375. https://doi.org/10.1007/978-1-4471-4670-4

Bakker, C., den Hollander, M., van Hinte, E., Zijlstra, Y., 2014. Products That Last - Product Design for Circular Business Models, TU Delft Library, Delft, Netherlands. TU Delft Library.

Bartolomeo, M., Dal Maso, D., De Jong, P., Eder, P., Groenewegen, P., Hopkinson, P., James, P., Nijhuis, L., Örninge, M., Scholl, G., Slob, A., Zaring, O., 2003. Eco-efficient producer services - What are they, how do they benefit customers and the environment and how likely are they to develop and be extensively utilised? J. Clean. Prod. 11, 829-837. https://doi.org/10.1016/S0959-6526(02)00157-9

Bell, S., Morse, S., 2008. Sustainability Indicators: Measuring the Immeasurable?, Second Edition Earthscan.London.Sterling,VA. https://doi.org/10.1016/S0743-0167(99)00036-4

Bhander, G.S., Hauschild, M., McAloone, T., 2003. Implementing life cycle assessment in product development. Environ. Prog. 22, 255-267. https://doi.org/10.1002/ep.670220414

Biolchini, J., Mian, P.G., Candida, A., Natali, C., 2005. Systematic Review in Software Engineering. Engineering 679, 1-31. https://doi.org/10.1007/978-3-540-70621-2

Bocken, N.M.P., de Pauw, I., Bakker, C., van der Grinten, B., 2016. Product design and business model strategies for a circular economy. J. Ind. Prod. Eng. 33, 308-320. https://doi.org/10.1080/21681015.2016.1172124

Bocken, N.M.P., Short, S.W., Rana, P., Evans, S., 2014. A literature and practice review to develop sustainable business model archetypes. J. Clean. Prod. 65, 42-56. https://doi.org/10.1016/j.jclepro.2013.11.039

Chengcheng Fan, Carrell, J.D., Hong-Chao Zhang, 2010. An investigation of indicators for measuring sustainable manufacturing. Proc. 2010 IEEE Int. Symp. Sustain. Syst. Technol. 1-5. https://doi.org/10.1109/ISSST.2010.5507764

Chou, C.J., Chen, C.W., Conley, C., 2015. An approach to assessing sustainable product-service systems. J. Clean. Prod. 86, 277-284. https://doi.org/10.1016/j.jclepro.2014.08.059 
Costa, M.H. da J., Oehmen, J., Rebentisch, E., Nightingale, D., 2014. Toward a better comprehension of Lean metrics for research and product development management. R D Manag. 44, 370-383. https://doi.org/10.1111/radm.12074

Dyllick, T., Hockerts, K., 2002. Beyond the business case for corporate sustainability. Bus. Strateg. Environ. 11, 130-141. https://doi.org/10.1002/bse.323

Elia, V., Gnoni, M.G., Tornese, F., 2017. Measuring circular economy strategies through index methods: A critical analysis. J. Clean. Prod. 142, 2741-2751. https://doi.org/10.1016/j.jclepro.2016.10.196

Elkington, J., 1998. ACCOUNTING FOR THE TRIPLE BOTTOM LINE. Meas. Bus. Excell. 2, 18-22. https://doi.org/https://doi.org/10.1108/eb025539

Ellen MacArthur Foundation, 2015. Growth within: a circular economy vision for a competitive europe. Ellen MacArthur Found. 100. https://doi.org/Article

EMF, 2017. A NEW TEXTILES ECONOMY: REDESIGNING FASHION'S FUTURE. Isle of Wight.

EMF, 2013. TOWARDS THE CIRCULAR ECONOMY, EMF - Ellen MacArthur Foundation. https://doi.org/10.1162/108819806775545321

Epstein, M.J., Roy, M.J., 2001. Sustainability in Action:Identifying and Measuring the Key Performance Drivers. Long Range Plann. 34, 585-604. https://doi.org/10.1016/S0024-6301(01)00084-X

European Commission, 2018. Bioeconomy [WWW Document]. URL https://ec.europa.eu/research/bioeconomy/index.cfm?pg=policy

European Commission, 2017. The Conflict Minerals Regulation [WWW Document]. URL http://ec.europa.eu/trade/policy/in-focus/conflict-minerals-regulation/regulation-explained/

European Commission, 2015. Closing the loop - An EU action plan for the Circular Economy.

Evans, S., Vladimirova, D., Holgado, M., Van Fossen, K., Yang, M., Silva, E.A., Barlow, C.Y., 2017. Business Model Innovation for Sustainability: Towards a Unified Perspective for Creation of Sustainable Business Models. Bus. Strateg. Environ. 26, 597-608. https://doi.org/10.1002/bse.1939

Falagas, M.E., Pitsouni, E.I., Malietzis, G.A., Pappas, G., 2007. Comparison of PubMed, Scopus, Web of Science, and Google Scholar: strengths and weaknesses. FASEB J. 22, 338-342. https://doi.org/10.1096/fj.07-9492LSF

Feil, A.A., de Quevedo, D.M., Schreiber, D., 2015. Selection and identification of the indicators for quickly measuring sustainability in micro and small furniture industries. Sustain. Prod. Consum. 3, 34-44. https://doi.org/10.1016/j.spc.2015.08.006

Fiksel, J., Mcdaniel, J., Spitzley, D., 1998. Measuring Product Sustainability. J. Sustain. Prod. Des.

Fiksel, J., Wapman, K., 1994. How to design for environment and minimize life cycle cost. Proc. 1994 IEEE Int. Symp. Electron. Environ. 75-80. https://doi.org/10.1109/ISEE.1994.337290

Gaiardelli, P., Saccani, N., Songini, L., 2006. Performance measurement systems in after-sales service: an integrated framework. Int. J. Bus. Perform. Manag. 9, 145. https://doi.org/10.1504/ijbpm.2007.011860

Gasparatos, A., Scolobig, A., 2012. Choosing the most appropriate sustainability assessment tool. Ecol. Econ. https://doi.org/10.1016/j.ecolecon.2012.05.005

Gavel, Y., Iselid, L., 2008. Web of Science and Scopus: a journal title overlap study. Online Inf. Rev. 32, 8-21. https://doi.org/10.1108/14684520810865958

Geissdoerfer, M., Morioka, S.N., de Carvalho, M.M., Evans, S., 2018. Business models and supply chains for the circular economy. J. Clean. Prod. 190, 712-721. https://doi.org/10.1016/j.jclepro.2018.04.159

Ghisellini, P., Cialani, C., Ulgiati, S., 2016. A review on circular economy: The expected transition to a balanced interplay of environmental and economic systems. J. Clean. Prod. 114, 11-32. https://doi.org/10.1016/j.jclepro.2015.09.007 
Haase, R.P., Pigosso, D.C.A., McAloone, T.C., 2017. Product/Service-System Origins and Trajectories: A Systematic Literature Review of PSS Definitions and their Characteristics. Procedia CIRP 64, 157-162. https://doi.org/10.1016/j.procir.2017.03.053

Hallstedt, S.I., 2017. Sustainability criteria and sustainability compliance index for decision support in product development. J. Clean. Prod. 140, 251-266. https://doi.org/10.1016/j.jclepro.2015.06.068

Hu, H.A., Chen, S.H., Hsu, C.W., Wang, C., Wu, C.L., 2012. Development of sustainability evaluation model for implementing product service systems. Int. J. Environ. Sci. Technol. 9, 343-354. https://doi.org/10.1007/s13762012-0037-7

Husgafvel, R., Pajunen, N., Päällysaho, M., Paavola, I.L., Inkinen, V., Heiskanen, K., Dahl, O., Ekroos, A., 2014. Social metrics in the process industry: Background, theory and development work. Int. J. Sustain. Eng. https://doi.org/10.1080/19397038.2013.800166

Ijomah, W.L., 2009. Addressing decision making for remanufacturing operations and design-for-remanufacture. Int. J. Sustain. Eng. 2, 91-102. https://doi.org/10.1080/19397030902953080

Issa, I.I., Pigosso, D.C.A., McAloone, T.C., Rozenfeld, H., 2015. Leading product-related environmental performance indicators: a selection guide and database. J. Clean. Prod. 108, 321-330. https://doi.org/10.1016/j.jclepro.2015.06.088

Jiménez-Rivero, A., García-Navarro, J., 2016. Indicators to Measure the Management Performance of End-of-Life Gypsum: From Deconstruction to Production of Recycled Gypsum. Waste and Biomass Valorization 7, 913-927. https://doi.org/10.1007/s12649-016-9561-x

Joung, C.B., Carrell, J., Sarkar, P., Feng, S.C., 2013. Categorization of indicators for sustainable manufacturing. Ecol. Indic. https://doi.org/10.1016/j.ecolind.2012.05.030

Kafa, N., Hani, Y., El Mhamedi, A., 2013. Sustainability performance measurement for green supply chain management, IFAC Proceedings Volumes (IFAC-PapersOnline). IFAC. https://doi.org/10.3182/20130911-3-BR-3021.00050

Kalmykova, Y., Sadagopan, M., Rosado, L., 2017. Circular economy - From review of theories and practices to development of implementation tools. Resour. Conserv. Recycl. 1-13. https://doi.org/10.1016/j.resconrec.2017.10.034

Kirchherr, J., Reike, D., Hekkert, M., 2017. Conceptualizing the circular economy: An analysis of 114 definitions. Resour. Conserv. Recycl. https://doi.org/10.1016/j.resconrec.2017.09.005

Kjaer, L.L., Pigosso, D.C.A., Niero, M., Bech, N.M., Mcaloone, T.C., 2018. Product/Service-Systems for a Circular Economy: The Route to Decoupling Economic Growth from Resource Consumption? J. Ind. Ecol. 00. https://doi.org/10.1111/jiec.12747

Korhonen, J., Honkasalo, A., Seppälä, J., 2018. Circular Economy: The Concept and its Limitations. Ecol. Econ. 143, 37-46. https://doi.org/10.1016/j.ecolecon.2017.06.041

Krajnc, D., Glavic, P., 2003. Indicators of sustainable production. Clean Technol. Environ. Policy 5, 279-288. https://doi.org/10.1007/s10098-003-0221-z

Labuschagne, C., Brent, A.C., Van Erck, R.P.G., 2005. Assessing the sustainability performances of industries. J. Clean. Prod. https://doi.org/10.1016/j.jclepro.2003.10.007

Lewis-Beck, M., 2004. The SAGE Encyclopedia of Social Science Research Methods. SAGE Encycl. Soc. Sci. Res. Methods. https://doi.org/http://dx.doi.org/10.4135/9781412950589

Lieder, M., Rashid, A., 2016. Towards circular economy implementation: A comprehensive review in context of manufacturing industry. J. Clean. Prod. 115, 36-51. https://doi.org/10.1016/j.jclepro.2015.12.042

Lu, T., Gupta, A., Jayal, A.D., Badurdeen, F., Feng, S.C., Dillon, O.W., Jawahir, I.S., 2010. A Framework of Product and Process Metrics for Sustainable Manufacturing. Adv. Sustain. Manuf. 333-338. https://doi.org/10.1007/978-3-642- 
20183-7

Lüdeke-Freund, F., 2010. Towards a conceptual framework of business models for sustainability, in: ERSCP-EMU Conference, Delft, The Netherlands, . pp. 1-28.

Ludeke-Freund, F., Freudenreich, B., Saviuc, I., Schaltegger, S., Stock, M., 2017. Sustainability-Oriented Business Model Assessment - A Conceptual Foundation, in: Carayannis, E., Sindakis, S. (Eds.), Analytics, Innovation, and Excellence-Driven Enterprise Sustainability. pp. 169-206. https://doi.org/10.1057/978-1-137-37879-8_1

McAloone, T.C., Pigosso, D.C.A., 2018. Ecodesign Implementation and LCA, in: Hauschild, M.Z., Rosenbaum, R.K., Olsen, S.I. (Eds.), Life Cycle Assessment: Theory and Practice. Springer International Publishing, Cham, pp. 545-576. https://doi.org/10.1007/978-3-319-56475-3_23

Moreau, V., Sahakian, M., van Griethuysen, P., Vuille, F., 2017. Coming Full Circle: Why Social and Institutional Dimensions Matter for the Circular Economy. J. Ind. Ecol. 21, 497-506. https://doi.org/10.1111/jiec.12598

Morioka, S.N., Carvalho, M.M., 2016. Measuring sustainability in practice: exploring the inclusion of sustainability into corporate performance systems in Brazilian case studies. J. Clean. Prod. 136, 123-133. https://doi.org/10.1016/j.jclepro.2016.01.103

Morioka, S.N., Evans, S., Carvalho, M.M. De, 2016. Sustainable Business Model Innovation: Exploring Evidences in Sustainability Reporting. Procedia CIRP 40, 660-668. https://doi.org/10.1016/j.procir.2016.01.151

Murray, A., Skene, K., Haynes, K., 2017. The Circular Economy: An Interdisciplinary Exploration of the Concept and Application in a Global Context. J. Bus. Ethics 140, 369-380. https://doi.org/10.1007/s10551-015-2693-2

Ness, B., Urbel-Piirsalu, E., Anderberg, S., Olsson, L., 2007. Categorising tools for sustainability assessment. Ecol. Econ. https://doi.org/10.1016/j.ecolecon.2006.07.023

Niero, M., Hauschild, M.Z., 2017. Closing the Loop for Packaging: Finding a Framework to Operationalize Circular Economy Strategies. Procedia CIRP 61, 685-690. https://doi.org/10.1016/j.procir.2016.11.209

Nightingale, A., 2009. A guide to systematic literature reviews. Surgery 27, 381-384. https://doi.org/10.1016/j.mpsur.2009.07.005

Okechukwu, E.C., Nwosu Moses, Chukwuneke Jeremiah, 2014. A Comparative Analysis of Cost of Rework and Cost of Conformance to Quality in Manufacturing Sector : A Case Study of Aluminium Industry in Nigeria.

Olugu, E.U., Wong, K.Y., Shaharoun, A.M., 2011. Development of key performance measures for the automobile green supply chain. Resour. Conserv. Recycl. 55, 567-579. https://doi.org/10.1016/j.resconrec.2010.06.003

Parkinson, H.J., Thompson, G., 2003. Analysis and taxonomy of remanufacturing industry practice. Proc. Inst. Mech. Eng. Part E-Journal Process Mech. Eng. 217, 243-256. https://doi.org/10.1243/095440803322328890

Pavlov, A., Bourne, M., 2011. Explaining the effects of performance measurement on performance: An organizational routines perspective. Int. J. Oper. Prod. Manag. 31, 101-122. https://doi.org/10.1108/01443571111098762

Pavlovskaia, E., 2014. Sustainability criteria: their indicators, control, and monitoring (with examples from the biofuel sector). Environ. Sci. Eur. 26, 1-12. https://doi.org/10.1186/s12302-014-0017-2

Persson, A., Stirna, J., 2009. The Practice of Enterprise Modeling, in: Second IFIPWG 8.1Working Conference, PoEM 2009 Stockholm, Sweden, November 18-19, 2009. pp. 29-46. https://doi.org/10.1007/978-3-642-32273-0

Pieroni, M.P.P., McAloone, T.C., Pigosso, D.C.A., 2019. Business model innovation for circular economy and sustainability: A review of approaches. J. Clean. Prod. 215, 198-216. https://doi.org/10.1016/j.jclepro.2019.01.036

Pojasek, R.B., 2009. Using Leading Indicators to Drive Sustainability Performance. Environ. Qual. Manag. https://doi.org/10.1002/tqem.20228

Pope, J., Annandale, D., Morrison-Saunders, A., 2004. Conceptualising sustainability assessment. Environ. Impact Assess. Rev. 24, 595-616. https://doi.org/10.1016/j.eiar.2004.03.001 
Pope, J., Bond, A., Hugé, J., Morrison-Saunders, A., 2017. Reconceptualising sustainability assessment. Environ. Impact Assess. Rev. https://doi.org/10.1016/j.eiar.2016.11.002

Potting, J., Hekkert, M., Worrell, E., Hanemaaijer, A., 2017. Circular Economy: Measuring innovation in the product chain - Policy report. PBL Netherlands Environ. Assess. Agency 42.

Ray, G., Barney, J.B., Muhanna, W.A., 2004. Capabilities, business processes, and competitive advantage: Choosing the dependent variable in empirical tests of the resource-based view. Strateg. Manag. J. 25, 23-37. https://doi.org/10.1002/smj.366

Reefke, H., Trocchi, M., 2013. Balanced scorecard for sustainable supply chains: Design and development guidelines. Int. J. Product. Perform. Manag. 62, 805-826. https://doi.org/10.1108/IJPPM-02-2013-0029

Reike, D., Vermeulen, W.J.V., Witjes, S., 2018. The circular economy: New or Refurbished as CE 3.0? - Exploring Controversies in the Conceptualization of the Circular Economy through a Focus on History and Resource Value Retention Options. Resour. Conserv. Recycl. 135, 246-264. https://doi.org/10.1016/j.resconrec.2017.08.027

Rizos, V., Behrens, A., van der Gaast, W., Hofman, E., loannou, A., Kafyeke, T., Flamos, A., Rinaldi, R., Papadelis, S., Hirschnitz-Garbers, M., Topi, C., 2016. Implementation of circular economy business models by small and mediumsized enterprises (SMEs): Barriers and enablers. Sustain. 8. https://doi.org/10.3390/su8111212

Rotmans, J., 2006. Tools for Integrated Sustainability Assessment: A two-track approach. Integr. Assess. J. 6, 35-57.

Saavedra, Y.M.B., Barquet, A.P.B., Rozenfeld, H., Forcellini, F.A., Ometto, A.R., 2013. Remanufacturing in Brazil: Case studies on the automotive sector. J. Clean. Prod. 53, 267-276. https://doi.org/10.1016/j.jclepro.2013.03.038

Sauvé, S., Bernard, S., Sloan, P., 2016. Environmental sciences, sustainable development and circular economy: Alternative concepts for trans-disciplinary research. Environ. Dev. 17, 48-56. https://doi.org/10.1016/j.envdev.2015.09.002

Searcy, C., 2012. Corporate Sustainability Performance Measurement Systems: A Review and Research Agenda. J. Bus. Ethics 107, 239-253. https://doi.org/10.1007/s10551-011-1038-z

Shahbazi, S., Jönsson, C., Wiktorsson, M., Kurdve, M., Bjelkemyr, M., 2018. Material efficiency measurements in manufacturing: Swedish case studies. J. Clean. Prod. 181, 17-32. https://doi.org/10.1016/j.jclepro.2018.01.215

Sousa-Zomer, T.T., Cauchick Miguel, P.A., 2015. The main challenges for social life cycle assessment (SLCA) to support the social impacts analysis of product-service systems. Int. J. Life Cycle Assess. 607-616. https://doi.org/10.1007/s11367-015-1010-8

Staikos, T., Rahimifard, S., 2007. An end-of-life decision support tool for product recovery considerations in the footwear industry. Int. J. Comput. Integr. Manuf. 20, 602-615. https://doi.org/10.1080/09511920701416549

Thierry, M., Salomon, M., Van Nunen, J., 1995. Strategic Issues in Product Recovery Management. Calif. Manage. Rev. 37. https://doi.org/10.1016/0024-6301(95)91628-8

Tukker, A., Tischner, U., 2006. New Business for Old Europe: Product-Service Development. Competitiveness and Sustainability. Greenleaf Publishing.

UN, n.d. United Nations Global Compact [WWW Document]. URL https://www.unglobalcompact.org/what-is-gc/ourwork/social

Ussui, P.R.S., 2013. Sustainability indicators for the product development process in the auto parts industry. 20th ISPE Int. Conf. Concurr. Eng. CE 2013 - Proc. 481-493. https://doi.org/10.3233/978-1-61499-302-5-481

Veleva, V., Ellenbecker, M., 2001. Indicators of sustainable production: Framework and methodology, Journal of Cleaner Production. https://doi.org/10.1016/S0959-6526(01)00010-5

von Geibler, J., Cordaro, F., Kennedy, K., Lettenmeier, M., Roche, B., 2016. Integrating resource efficiency in business strategies: A mixed-method approach for environmental life cycle assessment in the single-serve coffee value 
chain. J. Clean. Prod. 115, 62-74. https://doi.org/10.1016/j.jclepro.2015.12.052

von Geibler, J., Liedtke, C., Wallbaum, H., Schaller, S., 2006. Accounting for the social dimension of sustainability: Experiences from the biotechnology industry. Bus. Strateg. Environ. 15, 334-346. https://doi.org/10.1002/bse.540

Waas, T., Hugé, J., Block, T., Wright, T., Benitez-Capistros, F., Verbruggen, A., 2014. Sustainability assessment and indicators: Tools in a decision-making strategy for sustainable development. Sustain. 6, 5512-5534. https://doi.org/10.3390/su6095512

Watanabe, E.H., da Silva, R.M., Tsuzuki, M.S.G., Junqueira, F., dos Santos Filho, D.J., Miyagi, P.E., 2016. A Framework to Evaluate the Performance of a New Industrial Business Model. IFAC-PapersOnLine 49, 61-66. https://doi.org/10.1016/j.ifacol.2016.12.162

WBCSD, 2010. Vision 2050: The new agenda for business. Wbcsd 80. https://doi.org/10.1111/j.1530-9290.2009.00117.x

Wirtz, B.W., Pistoia, A., Ullrich, S., Göttel, V., 2016. Business Models: Origin, Development and Future Research Perspectives. Long Range Plann. 49, 36-54. https://doi.org/10.1016/j.Irp.2015.04.001

World Commission on Environment and Development, 1987. Our Common Future.

Xing, K., Wang, H.F., Qian, W., 2013. A sustainability-oriented multi-dimensional value assessment model for productservice development. Int. J. Prod. Res. 51, 5908-5933. https://doi.org/10.1080/00207543.2013.810349

Zhang, Z., Xue, B., Pang, J., Chen, X., 2016. The decoupling of resource consumption and environmental impact from economic growth in China: Spatial pattern and temporal trend. Sustain. 8. https://doi.org/10.3390/su8030222

Zink, T., Geyer, R., 2017. Circular Economy Rebound. J. Ind. Ecol. 21, 593-602. https://doi.org/10.1111/jiec.12545 